\title{
A Drug Repurposing Approach Towards Elucidating the Potential of Flavonoids as COVID-19 Spike Protein Inhibitors
}

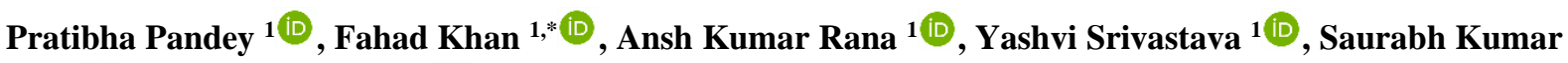 \\ Jha ${ }^{2}$ (D) , Niraj Kumar Jha ${ }^{2, *(D)}$ \\ 1 Department of Biotechnology, Noida Institute of Engineering and Technology, Greater Noida \\ 2 Department of Biotechnology, School of Engineering \& Technology (SET), Sharda University, Knowledge Park-III, \\ Institutional Area, Greater Noida 201310, India \\ * Correspondence: : niraj.jha@sharda.ac.in (N.K.J); fahadintegralian@gmail.com (F.K);
}

Scopus Author ID 55109018100 (N.K.J.); 57201049984 (F.K.);

Received: 3.07.2020; Revised: 25.07.2020; Accepted: 26.07.2020; Published: 28.07.2020

\begin{abstract}
The novel coronavirus (nCoV) has emerged as a severe public health threat globally in the 21 st century. Several therapies were reported towards identifying ligand against coronavirus, including targeting specific functional proteins or enzymes that are crucial to viruses, thereby preventing the synthesis and replication of virus RNA. Our study is mainly focused on targeting the virus's structural proteins, which could further block the binding of the virus to human cell receptors. In our study, we have selected nine Flavonoids for the inhibition of COVID-19 Spike protein, which have already been reported with their antiviral efficacies against other virus-infected diseases. AutoDock and PatchDock were used to study the inhibitory potential of flavonoids against COVID-19. Amongst all the eleven screened compounds, baicalin has depicted the highest binding affinity against 2019-nCoV spike glycoprotein. Additionally, we have also compared its potential with two standard HIV drugs Abacavir and hydroxychloroquine, and the docking results clearly revealed the better inhibitory potential of baicalin in comparison to recently used drug Abacavir and hydroxychloroquine for the treatment of COVID-19. Therefore our experimental findings strongly suggested that baicalin can be used as a potential inhibitor against COVID-19 spike protein, which could inhibit the interaction of the virus with the host cell and thus could provide a potential lead molecule for the development of a drug against COVID-19 disease.
\end{abstract}

Keywords: spike glycoprotein; SARS-CoV-2; coronavirus outbreak; flavonoids; molecular docking; drug repurposing.

(C) 2020 by the authors. This article is an open-access article distributed under the terms and conditions of the Creative Commons Attribution (CC BY) license (https://creativecommons.org/licenses/by/4.0/).

\section{Introduction}

Till twenty-first century, COVID-19 Coronavirus (CoV) has presented three major outbreak of respiratory distress syndrome, including SARS-CoV (severe acute respiratory distress syndrome, 2003) [1], MERS-CoV (Middle East respiratory syndrome, 2012) [2] and COVID-2019 (Coronavirus disease, 2019). To date, no approved vaccine or antiviral for coronavirus (CoVs) management. Literature reported the first incidence of SARS CoV-2 in Wuhan city of China in December 2019 that has now been migrated globally and emerged as a major threat to mankind [3]. CoVs are enveloped single-stranded RNA viruses that have been reported to infect both humans and animals with a high recombination rate [4]. Common 
symptoms associated with COVID-19 include high fever, coughing, convulsions, dizziness, and lymphopenia [5].

Nowadays, Drug repurposing is gaining wider attention over elucidating new drugs for disease management due to the slow pace and high attrition rates associated with new drugs [6]. It includes the utilization of previously reported compounds with numerous benefits such as low development cost and lesser development timelines. Our study is also based on such emerging concept by focusing on flavonoids which have shown considerable antiviral activities against numerous viral diseases including HIV (Human Immunodeficiency Syndrome), Adenoviruses (ADV), Herpes simplex virus (HSV-1 and HSV-2), Hepatitis C virus (HCV) and poliovirus type 2 . Through a literature search, $\mathrm{CoV}$ spike $(\mathrm{S})$ glycoprotein has gained greater attention towards being utilized as a key target for the development of drugs, vaccines, diagnostics, and therapeutic antibodies [7]. The entry of coronavirus into host cells is mediated by the glycoprotein (transmembrane spike $S$ ) that consists of two functional subunits: $S 1$ subunit for its binding to host cell receptor and S2 subunit for the fusion between cellular and viral membranes [8]. Therefore we have selected nine flavonoids to elucidate a potent inhibitory compound targeting this crucial $\mathrm{CoV}$ spike glycoprotein, which could further add to the drug development for the management of COVID-19. Thus our main objective is to elucidate the binding interaction of flavonoids and $\mathrm{CoV}$ spike glycoprotein by using molecular docking approaches.

\section{Materials and Methods}

\subsection{Preparation of receptor (Target structure).}

Structure of Target protein of COVID-19 2019-nCoV spike glycoprotein (PDB-ID: 6VSB) was downloaded from the protein data bank (RCSB PDB) database (Figure 1). The target structure was then optimized using Discovery studio and Autodock tool for molecular docking.

Amino Acid Sequence (FASTA) of Prefusion 2019-nCoV spike glycoprotein with a single receptor-binding domain up $P D B I D:$ (6VSB)

MFVFLVLLPLVSSQCVNLTTRTQLPPAYTNSFTRGVYYPDKVFRSSVLHSTQDLFLPF FSNVTWFHAIHVSGTNGTKRFDNPVLPFNDGVYFASTEKSNIIRGWIFGTTLDSKTQS LLIVNNATNVVIKVCEFQFCNDPFLGVYYHKNNKSWMESEFRVYSSANNCTFEYVS QPFLMDLEGKQGNFKNLREFVFKNIDGYFKIYSKHTPINLVRDLPQGFSALEPLVDLP IGINITRFQTLLALHRSYLTPGDSSSGWTAGAAAYYVGYLQPRTFLLKYNENGTITDA VDCALDPLSETKCTLKSFTVEKGIYQTSNFRVQPTESIVRFPNITNLCPFGEVFNATRF ASVYAWNRKRISNCVADYSVLYNSASFSTFKCYGVSPTKLNDLCFTNVYADSFVIRG DEVRQIAPGQTGKIADYNYKLPDDFTGCVIAWNSNNLDSKVGGNYNYLYRLFRKSN LKPFERDISTEIYQAGSTPCNGVEGFNCYFPLQSYGFQPTNGVGYQPYRVVVLSFELL HAPATVCGPKKSTNLVKNKCVNFNFNGLTGTGVLTESNKKFLPFQQFGRDIADTTD AVRDPQTLEILDITPCSFGGVSVITPGTNTSNQVAVLYQDVNCTEVPVAIHADQLTPT WRVYSTGSNVFQTRAGCLIGAEHVNNSYECDIPIGAGICASYQTQTNSPGSASSVASQ SIIAYTMSLGAENSVAYSNNSIAIPTNFTISVTTEILPVSMTKTSVDCTMYICGDSTECS NLLLQYGSFCTQLNRALTGIAVEQDKNTQEVFAQVKQIYKTPPIKDFGGFNFSQILPD PSKPSKRSFIEDLLFNKVTLADAGFIKQYGDCLGDIAARDLICAQKFNGLTVLPPLLTD EMIAQYTSALLAGTITSGWTFGAGAALQIPFAMQMAYRFNGIGVTQNVLYENQKLIA NQFNSAIGKIQDSLSSTASALGKLQDVVNQNAQALNTLVKQLSSNFGAISSVLNDILS 
RLDPPEAEVQIDRLITGRLQSLQTYVTQQLIRAAEIRASANLAATKMSECVLGQSKRV DFCGKGYHLMSFPQSAPHGVVFLHVTYVPAQEKNFTTAPAICHDGKAHFPREGVFV SNGTHWFVTQRNFYEPQIITTDNTFVSGNCDVVIGIVNNTVYDPLQPELDSFKEELDK YFKNHTSPDVDLGDISGINASVVNIQKEIDRLNEVAKNLNESLIDLQELGKYEQGSGY IPEAPRDGQAYVRKDGEWVLLSTFLGRSLEVLFQGPGHHHHHHHHSAWSHPQFEKG GGSGGGGSGGSAWSHPQFEK

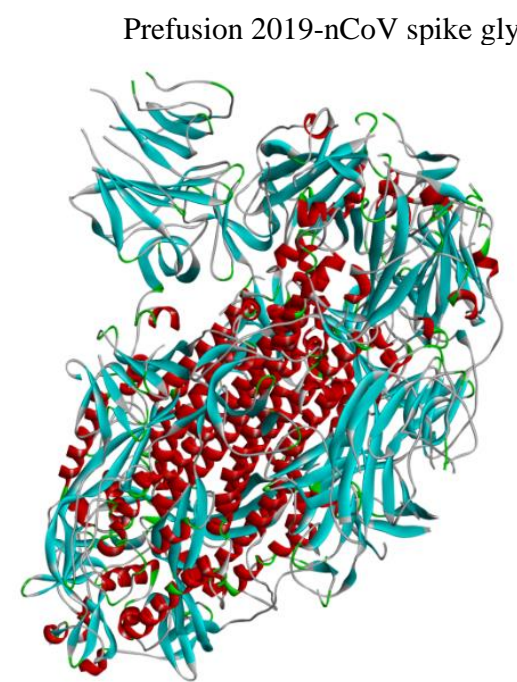

Ribbon Structure Representation



Surface Representation

Figure 1. FASTA sequence and crystal structure of 2019-nCoV spike glycoprotein with a single receptorbinding domain (6VSB). (A) Ribbon Structure (B)Surface Representation.

\subsection{Ligand selection and Preparation.}

All the selected 9 flavonoids and two standard drugs were selected for docking analysis, and their 3D structure was downloaded from the PubChem database.

\subsection{Manual Docking protocol using AutoDock 4.2.}

Screening of all the nine phytocompounds was done by using AutoDock 4.2 software [9]. AutoDock tool was used to identify the best ligand binding conformation in the target protein. This tool utilizes the scoring function for analyzing the binding conformations through free binding energy. Subsequent docking steps were followed as per the protocol followed by Rizvi et al., 2013.

\subsection{Docking through Online server (PatchDock).}

PatchDock [10] is a freely available online docking server based on a geometry based docking algorithm (http://bioinfo3d.cs.tau.ac.il/PatchDock/). All the nine phytocompounds were docked with 2019-nCoV spike glycoprotein (PDB-ID: 6VSB) for the validation of results obtained by manual docking with the help of AutoDock 4.2 Software.

\subsection{Drug Likeliness Filters.}

Four different filters, including Lipinski's Rule of Five, Ghose filter, Veber Filter, and Mudgee filter, are used in this study to identify the drug likeliness criteria for selected Flavonoids. Selected compounds were screened by Lipinski's rule of five which clearly states 
that compound should meet these criteria including molecular mass (less than 500 daltons), hydrogen bond donors (no more than 5), hydrogen bond acceptors (no more than 10), log P (octanol-water partition coefficient not greater than 5). Compounds having three or more three Voilations are rejected since they do not fulfill the criteria of drug likeliness. Ghose filter criteria include Molecular weight (between 160 and 480), $\operatorname{LogP}$ (between -0.4 and +5.6), Atom count (between 20 and 70), Molar refractivity (between 40 and 130). Veber filter criteria include parameters like Rotatable bonds $(<=10)$, Topological polar surface area $(<=140)$. Muegge filter criteria include the Number of Rings ( $>=3)$, Number of Rigid bonds $(>=18)$, Number of Rotatable bonds $(>=6)$.

\section{Results and Discussion}

\subsection{Selection of flavonoids (Phytocompounds) for the docking analysis.}

In order to elucidate a potent lead candidate for the treatment of COVID-19, we have selected 9 flavonoids for our study. Through a literature search, it was found that all the selected nine phytocompounds have depicted significant inhibitory potential against several viral diseases, including HIV and Hepatitis, etc. via several ways such as DNA polymerase inhibition, inhibition of reverse-transcriptase and protease inhibition, etc. We have shown the list of compounds with their class and antiviral efficacy (Table 1) for docking analysis against 2019-nCoV spike glycoprotein. We have selected two standard drugs that are Abacavir and hydroxychloroquine for our study as they currently being used for the treatment of COVID-19 [11].

Table 1. Screened compounds and their reported antiviral efficacies.

\begin{tabular}{|c|c|c|c|c|}
\hline S.No. & Compound Name & Pubchem ID & Class & Reported Antiviral Efficacy \\
\hline 1. & Baicalin & 64982 & $\begin{array}{l}\text { Flavonoid } \\
\text { FDA Approved Drug }\end{array}$ & $\begin{array}{l}\text { - Inhibitor of HIV-1 production in } \\
\text { vitro [12] } \\
\text { - As Zika virus inhibitors [13] } \\
\text { - Inhibits the entry of the virus into } \\
\text { the host cell [14] [3] } \\
\text { - Anti-HIV Potency }[15,16]\end{array}$ \\
\hline 2. & Curcumin & 969516 & $\begin{array}{l}\text { Flavonoid } \\
\text { FDA Approved Drug }\end{array}$ & $\begin{array}{l}\text { - Effect of curcumin on energy } \\
\text { metabolism in HIV infection [16] } \\
\text { - Impact of curcumin on oxidative } \\
\text { stress, glycemic profile and } \\
\text { inflammatory markers in HIV infected } \\
\text { individuals [17] } \\
\text { - A potent anti HIV agent }[18,19]\end{array}$ \\
\hline 3. & Galangin & 5281616 & $\begin{array}{l}\text { Flavonoid } \\
\text { FDA Approved Drug }\end{array}$ & $\begin{array}{l}\text { - Anti HIV potential }[20,22] \\
\text { - HIV-1 proteinase inhibitors [21] }\end{array}$ \\
\hline 4. & Morin & 5281670 & $\begin{array}{l}\text { Flavonoid } \\
\text { FDA Approved Drug }\end{array}$ & $\begin{array}{l}\text { - Promising antiviral drugs [23] } \\
\text { - Potent inhibitor of Helicobacter } \\
\text { pylori urease [24] }\end{array}$ \\
\hline 5. & Quercetin & 5280343 & $\begin{array}{l}\text { Flavonoid } \\
\text { FDA Approved Drug }\end{array}$ & $\begin{array}{l}\text { - Antiviral agent [25] } \\
\text { - Efficacy against Zika virus infection } \\
\text { [26] } \\
\text { - Effective against Hepatitis C virus } \\
\text { [27] } \\
\text { - Antiviral efficacy against murine } \\
\text { norovirus [28] }\end{array}$ \\
\hline 6. & Scutellarein & 5281697 & $\begin{array}{l}\text { Flavonoid } \\
\text { FDA Approved Drug }\end{array}$ & $\begin{array}{l}\text { - Antiviral compounds [29] } \\
\text { - Inhibitor of SARS-CoV helicase } \\
\text { protein [30] } \\
\text { - Potent efficacy against coronavirus } \\
{[31,32]}\end{array}$ \\
\hline
\end{tabular}




\begin{tabular}{|c|c|c|c|c|}
\hline S.No. & Compound Name & Pubchem ID & Class & Reported Antiviral Efficacy \\
\hline 7. & Silibinin & 31553 & Flavonoid & $\begin{array}{l}\text { - Antiviral potential [33] } \\
\text { - Antiviral agent for Enterovirus A71 } \\
\text { [34] }\end{array}$ \\
\hline 8. & Myricetin & 5281672 & $\begin{array}{l}\text { Flavonoid } \\
\text { FDA Approved Drug }\end{array}$ & $\begin{array}{l}\text { - Antiviral potential [35] } \\
\text { - Inhibitory role against Herpes } \\
\text { simplex virus [36] } \\
\text { - Anti HIV-1 potential in vitro [37] }\end{array}$ \\
\hline 9. & Epigallocatechin & 72277 & Flavonoid & $\begin{array}{l}\text { - Antiviral potential against Nile } \\
\text { virus, dengue virus, and Zika virus [38] } \\
\text { - Antivirus efficacy against reovirus } \\
\text { [39] }\end{array}$ \\
\hline 10. & Abacavir & 441300 & $\begin{array}{lcc}\text { Standard } & \text { Drug for } \\
\text { COVID-19 treatment } & \\
\end{array}$ & $\begin{array}{l}\text { - Drug for the treatment of COVID- } \\
19[40,41,42]\end{array}$ \\
\hline 11. & Hydroxychloroquine & 3652 & $\begin{array}{lcc}\text { Standard } & \text { Drug } & \text { for } \\
\text { COVID-19 treatment } & \end{array}$ & $\begin{array}{l}- \text { Drug used for the treatment of } \\
\text { COVID-19 }[43,44,45]\end{array}$ \\
\hline
\end{tabular}

Table 2. Molecular docking analysis of antiviral compounds against Prefusion 2019-nCoV spike glycoprotein

\begin{tabular}{|c|c|c|c|c|}
\hline \multirow{12}{*}{$\begin{array}{l}\text { Prefusion } \\
\text { 2019-nCoV } \\
\text { spike } \\
\text { glycoprotein } \\
\text { with a single } \\
\text { receptor- } \\
\text { binding } \\
\text { domain up } \\
\text { (6VSB) }\end{array}$} & Compound & $\begin{array}{l}\text { Binding } \\
\text { Affinity } \\
\text { (Kcal/mol) }\end{array}$ & $\begin{array}{l}\text { No. of } \mathbf{H} \\
\text { bond }\end{array}$ & Amino Acid Residues \\
\hline & Baicalin & -7.26 & 2 & $\begin{array}{l}\text { Lys964, Gln965, Leu962, Thr961, Ser1003, Ala958, } \\
\text { Tyr1007, Gln1011, Gln1010, Agr1014 }\end{array}$ \\
\hline & Curcumin & -6.53 & 0 & $\begin{array}{l}\text { Gln954, Ala958, Arg1014, Gln967, } \\
\text { Leu962, Gln1010, Tyr1007, Thr1006, } \\
\text { Gln1002, Gly999, Phe970 }\end{array}$ \\
\hline & Galangin & -6.39 & 1 & $\begin{array}{l}\text { Thr998, Leu1001, Gln1002, Thr1006, Gln1005, } \\
\text { Thr1009, Gln1002, Thr1006, Gln1005, Thr1009, } \\
\text { Gln1010 }\end{array}$ \\
\hline & Morin & -6.09 & 2 & $\begin{array}{l}\text { Gln1010, Thr1009, Tyr1007, Thr1006, Gln1005, } \\
\text { Gln1002, Thr1006, Gln1005, Thr1009, Gln1002 }\end{array}$ \\
\hline & Quercetin & -5.74 & 1 & $\begin{array}{l}\text { Gly999, Gln965, Leu962, } \text { Thr961, Leu1004, } \\
\text { Ala958, Tyr1007, Gln1010, Thr1006, Ser1003, } \\
\text { Gln1002 }\end{array}$ \\
\hline & Scutellarein & -6.74 & 1 & $\begin{array}{l}\text { Gln1002, Ser1003, Leu1004, Gln965, } \\
\text { Leu962, Thr1007, } \\
\text { Arg1014, Gln1010, Thr1006 }\end{array}$ \\
\hline & Silibinin & -6.73 & 1 & $\begin{array}{l}\text { Phe970, Gln965, Leu962, Thr961, Gln957, Ala958, } \\
\text { Gln954, Arg1014, Gln1011, Tyr1007, Gln1010, } \\
\text { Thr1006, Ser1003, Gln1002 }\end{array}$ \\
\hline & Myricetin & -6.15 & 0 & $\begin{array}{l}\text { Gln1002, Thr1006, Gln1002, Gln1005, Thr1009, } \\
\text { Gln1005, Thr1006, Tyr1007, Thr1009, Gln1010, } \\
\text { Ile1013 }\end{array}$ \\
\hline & Epigallocatechin & -5.28 & 0 & $\begin{array}{l}\text { Ala958, Gln1010, Tyr1007, Leu962, } \\
\text { Gln965, Ser1003, Thr1006, Gln1002, } \\
\text { Phe970 }\end{array}$ \\
\hline & Abacavir & -4.99 & 0 & $\begin{array}{l}\text { Gln1010, Thr1009, Gln1005, Thr1009, Gln1005, } \\
\text { Thr1006, Gln1002, Leu1001, Thr998, Gln1002, } \\
\text { Thr1006 }\end{array}$ \\
\hline & $\begin{array}{l}\text { Hydroxychloroqui } \\
\text { ne }\end{array}$ & -3.61 & 0 & $\begin{array}{l}\text { Glr957, Thr961, Ala958, Gln965, Leu962, Phe970, } \\
\text { Tyr1007, Ser1003, Gly999, Thr1006, Gln1010, } \\
\text { Thr998, Gln1002 }\end{array}$ \\
\hline
\end{tabular}

\subsection{Molecular docking using AutoDock 4.2 software.}

Molecular docking analysis was done by using the most potent tool that is AutoDock tool 4.2. The binding energies of selected Flavonoids were illustrated in Table 2. The docking results exhibited that all the 9 phytocompounds (flavonoids) showed the best binding energies against 2019-nCoV spike glycoprotein in comparison to the standard drugs used against COVID-19 (Figure 2 to Figure 12). Although all the selected phytocompounds have exhibited better binding affinity in comparison to the two standard drugs, baicalin exhibited the bestdocked score $(-7.26 \mathrm{Kcal} / \mathrm{mol})$ against 2019-nCoV spike glycoprotein (Figure 13) in comparison to the standard drugs Abacavir and hydroxychloroquine(Figure 14). Table 2 
depicts the binding affinity ( $\mathrm{Kcal} / \mathrm{mol})$, the number of Hydrogen bonds formed, and participating amino acid residues in the interaction with 2019-nCoV spike glycoprotein.

2019-nCoV spike glycoprotein

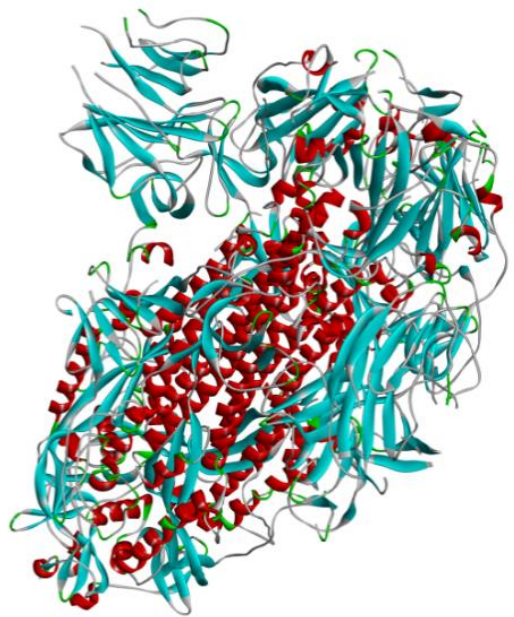

2(A) Receptor/Protein

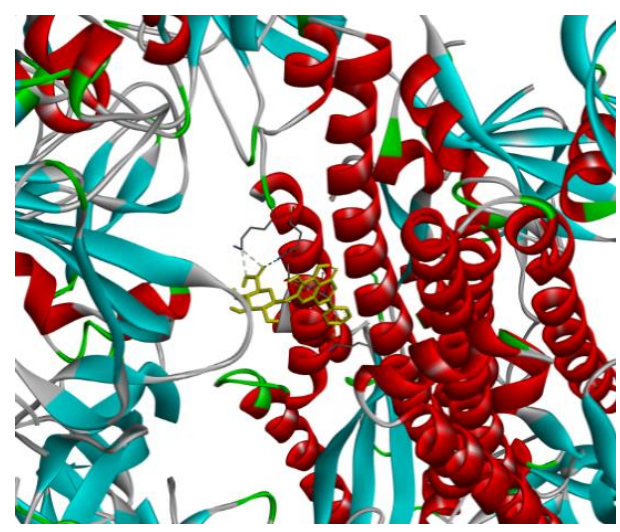

2(C) Protein-Ligand interaction
Baicalin

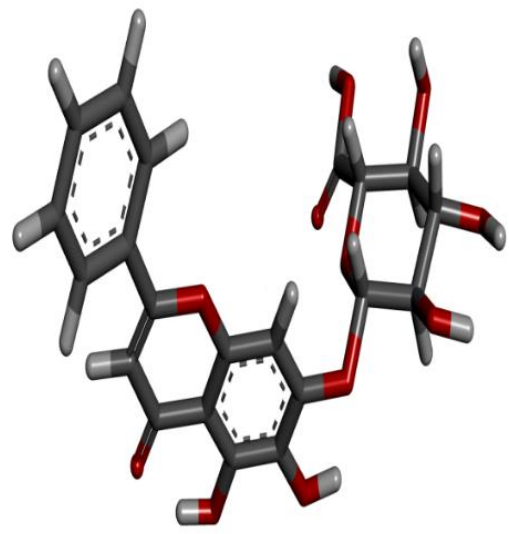

2(B) Ligand

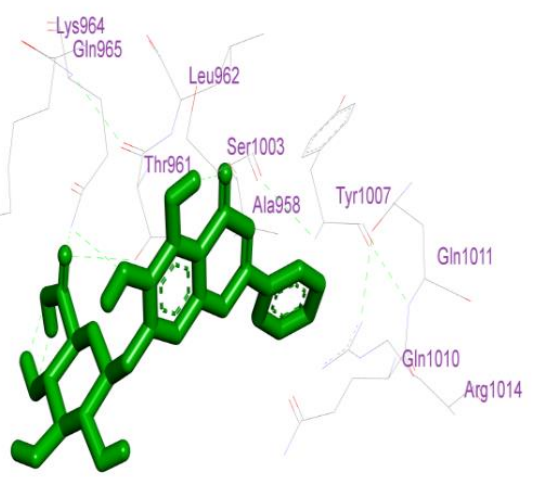

2(D) Ligand participating in amino acid interaction

Figure 2. Molecular docking analysis between 6VSB and baicalin. (A) 3D ribbon structure of 2019-nCoV spike glycoprotein (6VSB). (B) 3D ligand structure (Baicalin). (C) Protein-ligand Interaction. (D) Interaction between the active site residues of ligand and protein.

\subsection{Validation of docking results with the help of PatchDock (an online docking server).}

Further, an online server was used to validate the docking results, and similar findings were obtained with the PatchDock server. Baicalin has shown maximum patch dock score and ACE value in comparison to other selected flavonoids and standard drugs (Abacavir and hydroxychloroquine) (Table 3 ).

\subsection{Phytocompounds following criteria of drug likeliness.}

Additionally, we have also performed screening of compounds by employing other filters, also including Ghose filter, Veber filter, and Muegge Filter. Table 4 and Table 5 clearly establish that all the compounds have followed the drug likeliness criteria using all four different filters except baicalin only passes Lipinski's Rule of Five (with 2 voilations) and Ghose filter. 


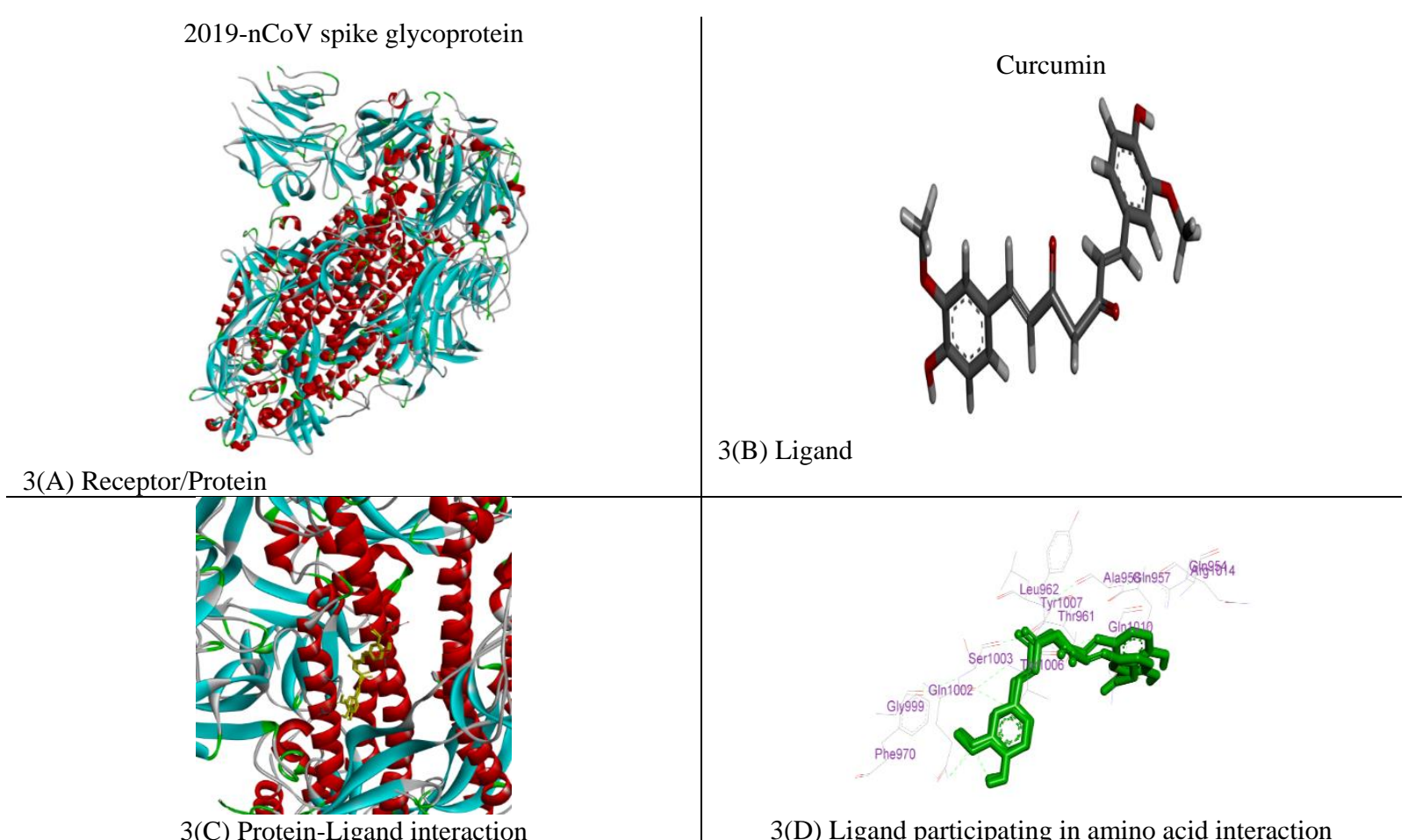

Figure 3. Molecular docking analysis between 6VSB and Curcumin. (A) 3D ribbon structure of 2019-nCoV spike glycoprotein (6VSB). (B) 3D ligand structure (Curcumin). (C) Protein-ligand Interaction. (D) Interaction between the active site residues of ligand and protein.

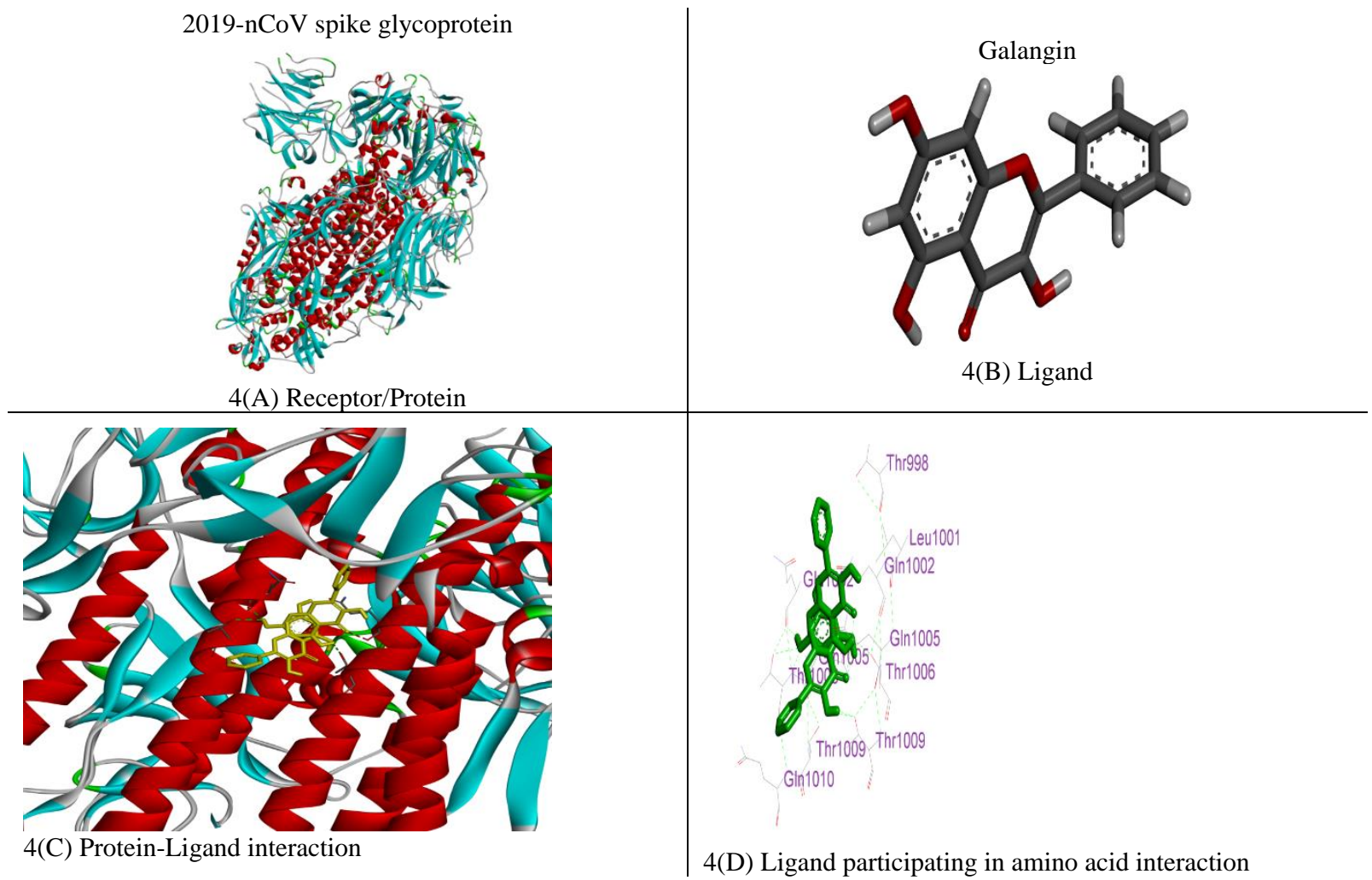

Figure 4. Molecular docking analysis between 6VSB and Galangin (A) 3D ribbon structure of 2019-nCoV spike glycoprotein (6VSB). (B) 3D ligand structure (Galangin). (C) Protein-ligand Interaction. (D) Interaction between the active site residues of ligand and protein.

\subsection{Comparative analysis with standard drug Abacavir and hydroxychloroquine.}

The further binding affinity of the selected flavonoids was compared with the binding affinity of the two currently drugs (Abacavir and hydroxychloroquine) used for the treatment 
of COVID-19. Our findings clearly state that all the phytocompounds have better inhibitory potential (binding affinity) against COVID-19 in comparison to the standard drugs. However, baicalin has exhibited the best binding affinity than Abacavir and hydroxychloroquine (Figure $13)$.

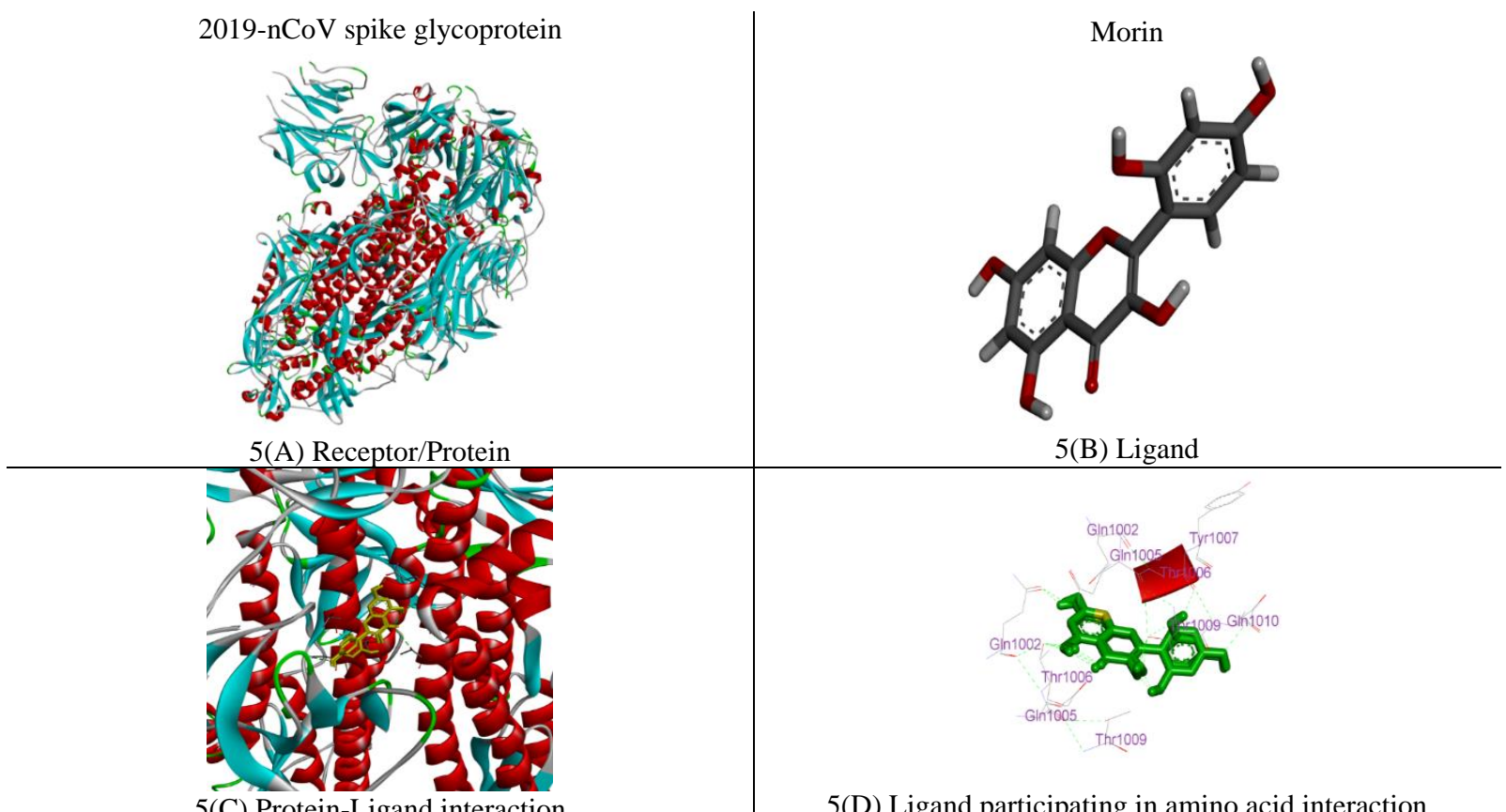

Figure 5. Molecular docking analysis between 6VSB and Morin. (A) 3D ribbon structure of 2019-nCoV spike glycoprotein (6VSB). (B) 3D ligand structure (Morin). (C) Protein-ligand Interaction. (D) Interaction between the active site residues of ligand and protein.

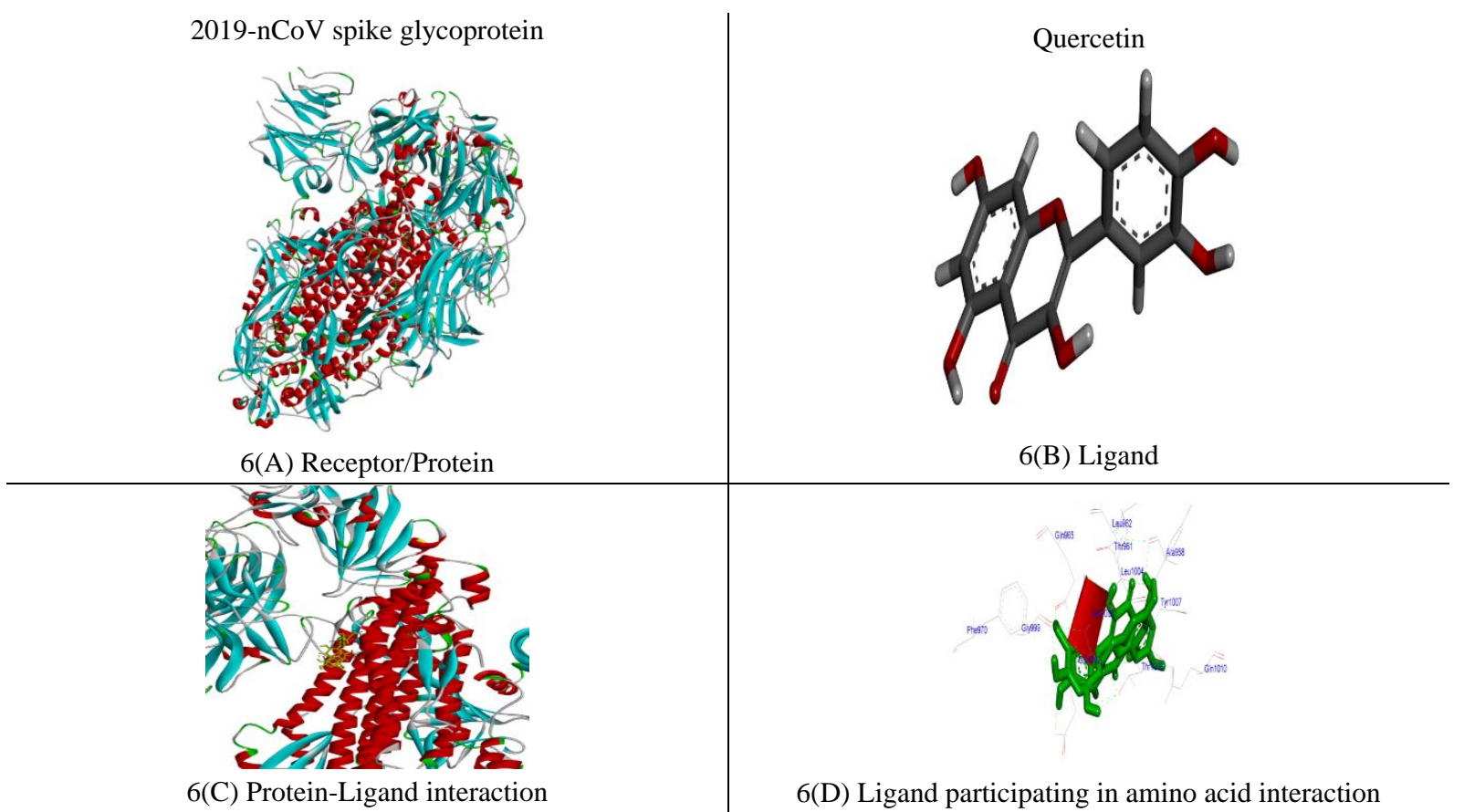

Figure 6. Molecular docking analysis between 6VSB and Quercetin. (A) 3D ribbon structure of 2019-nCoV spike glycoprotein (6VSB). (B) 3D ligand structure (Quercetin). (C) ligand Interaction. (D) Interaction between the active site residues of ligand and protein. 


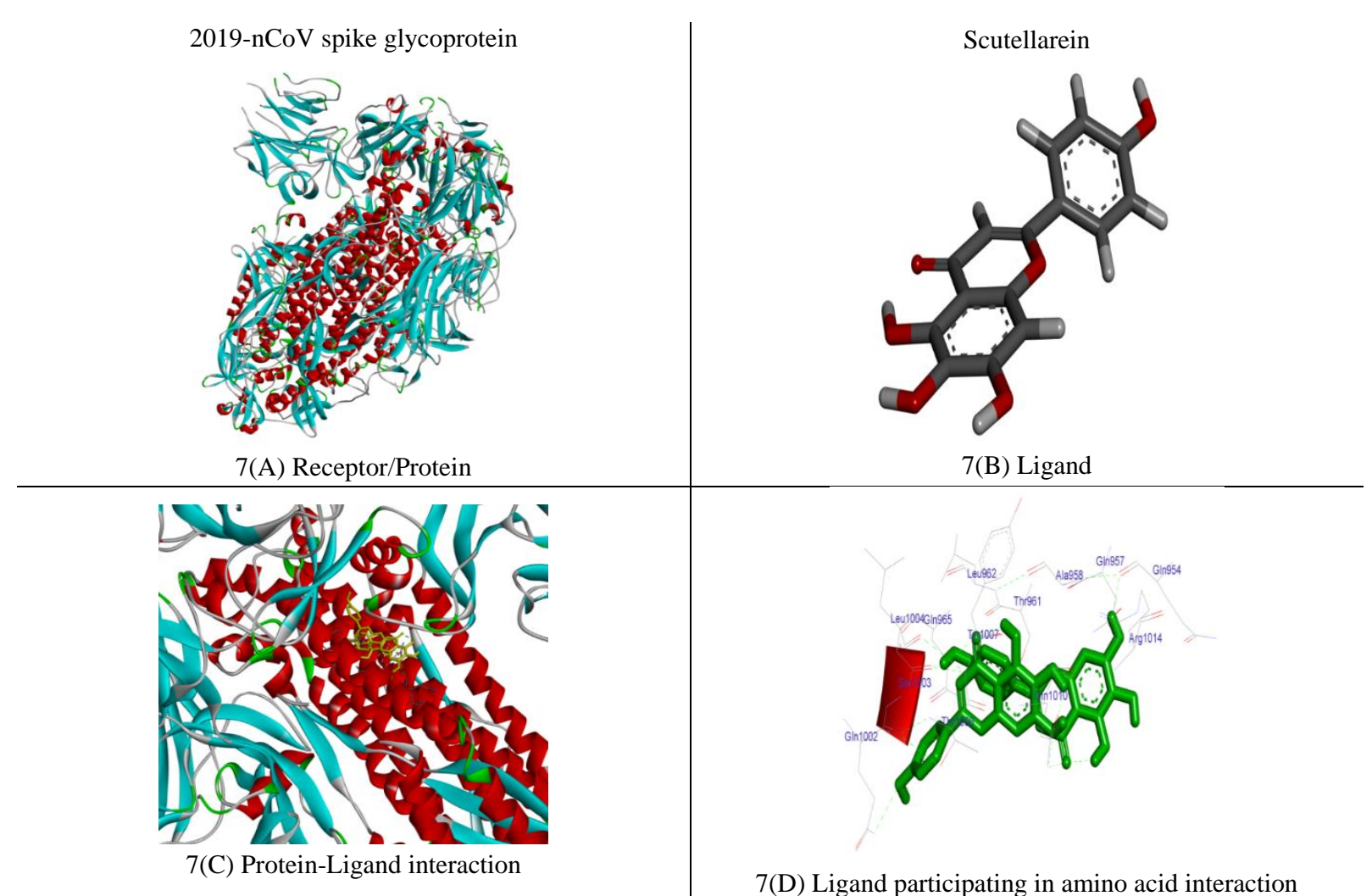

Figure 7. Molecular docking analysis between 6VSB and Scutellarein. (A) 3D ribbon structure of 2019-nCoV spike glycoprotein (6VSB). (B) 3D ligand structure (Scutellarein). (C) Protein-ligand Interaction. (D) Interaction between the active site residues of ligand and protein.

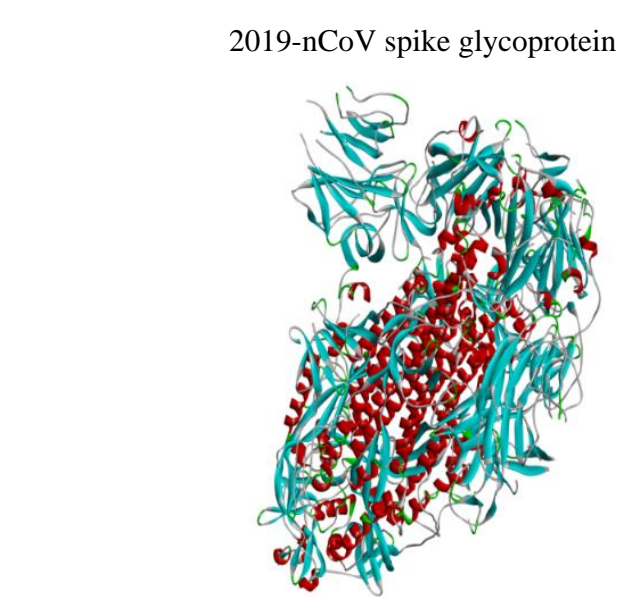

8(A) Receptor/Protein

8(C) Protein-Ligand interaction

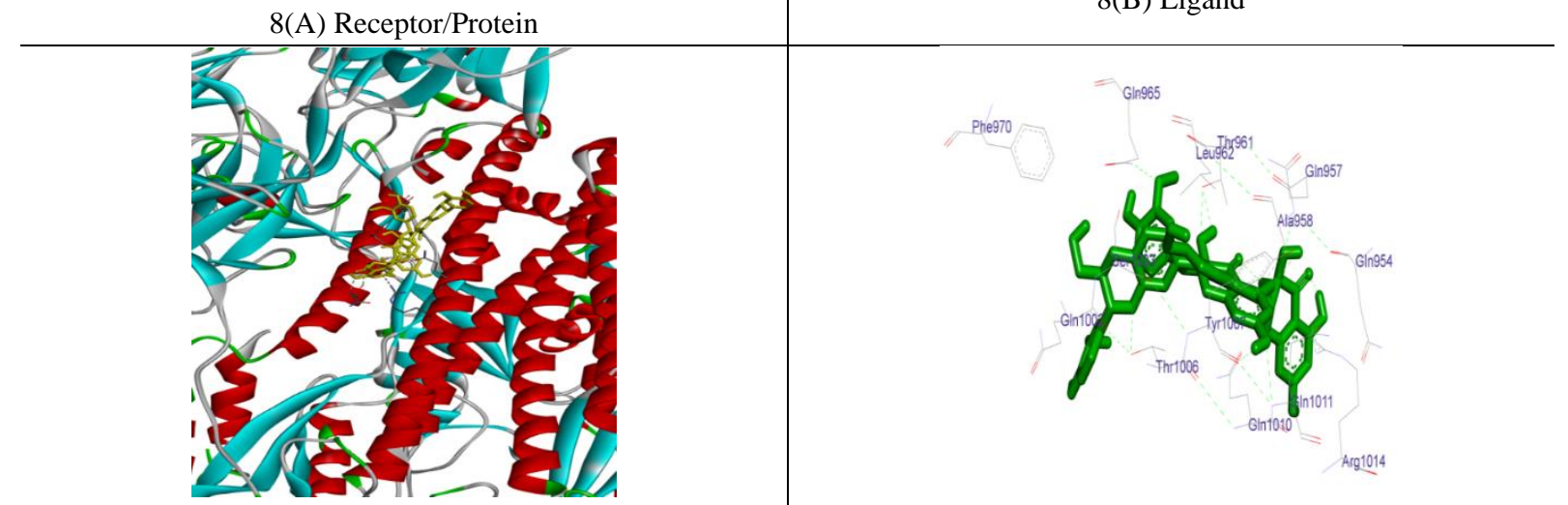

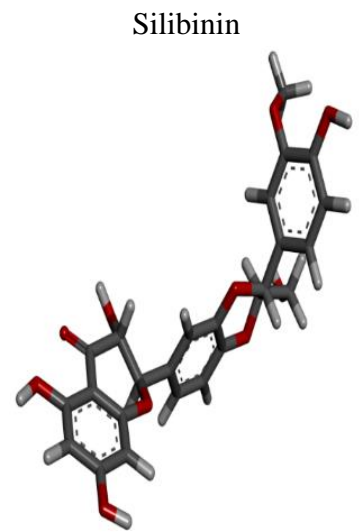

8(B) Ligand

8(D) Ligand participating in amino acid interaction

Figure 8. Molecular docking analysis between 6VSB and Silibinin. (A) 3D ribbon structure of 2019-nCoV spike glycoprotein (6VSB). (B) 3D ligand structure (Silibinin). (C) Protein-ligand Interaction. (D) Interaction between the active site residues of ligand and protein. 


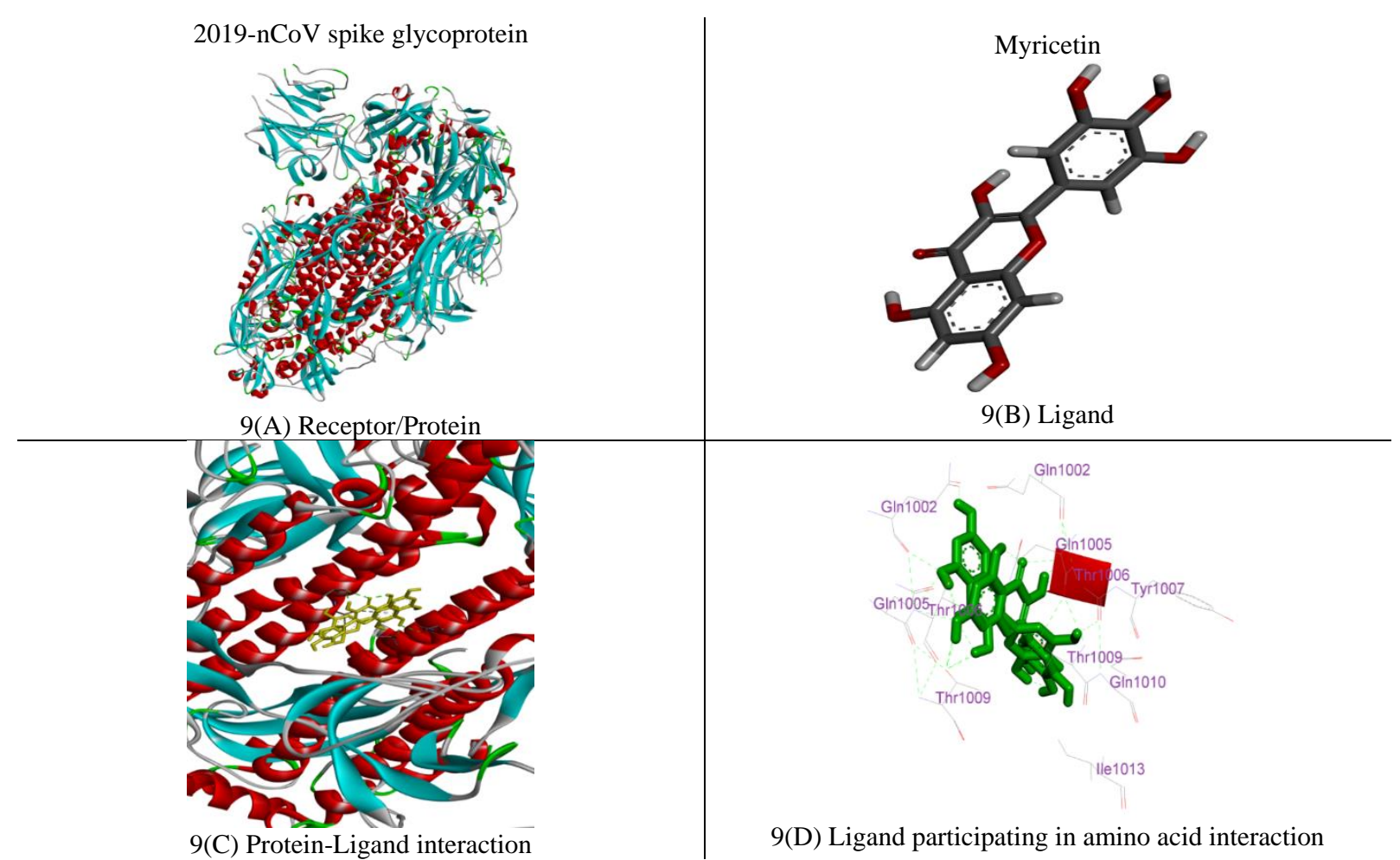

Figure 9. Molecular docking analysis between 6VSB and Myricetin. (A) 3D ribbon structure of 2019-nCoV spike glycoprotein (6VSB). (B) 3D ligand structure (Myricetin). (C) Protein-ligand Interaction. (D) Interaction between the active site residues of ligand and protein.

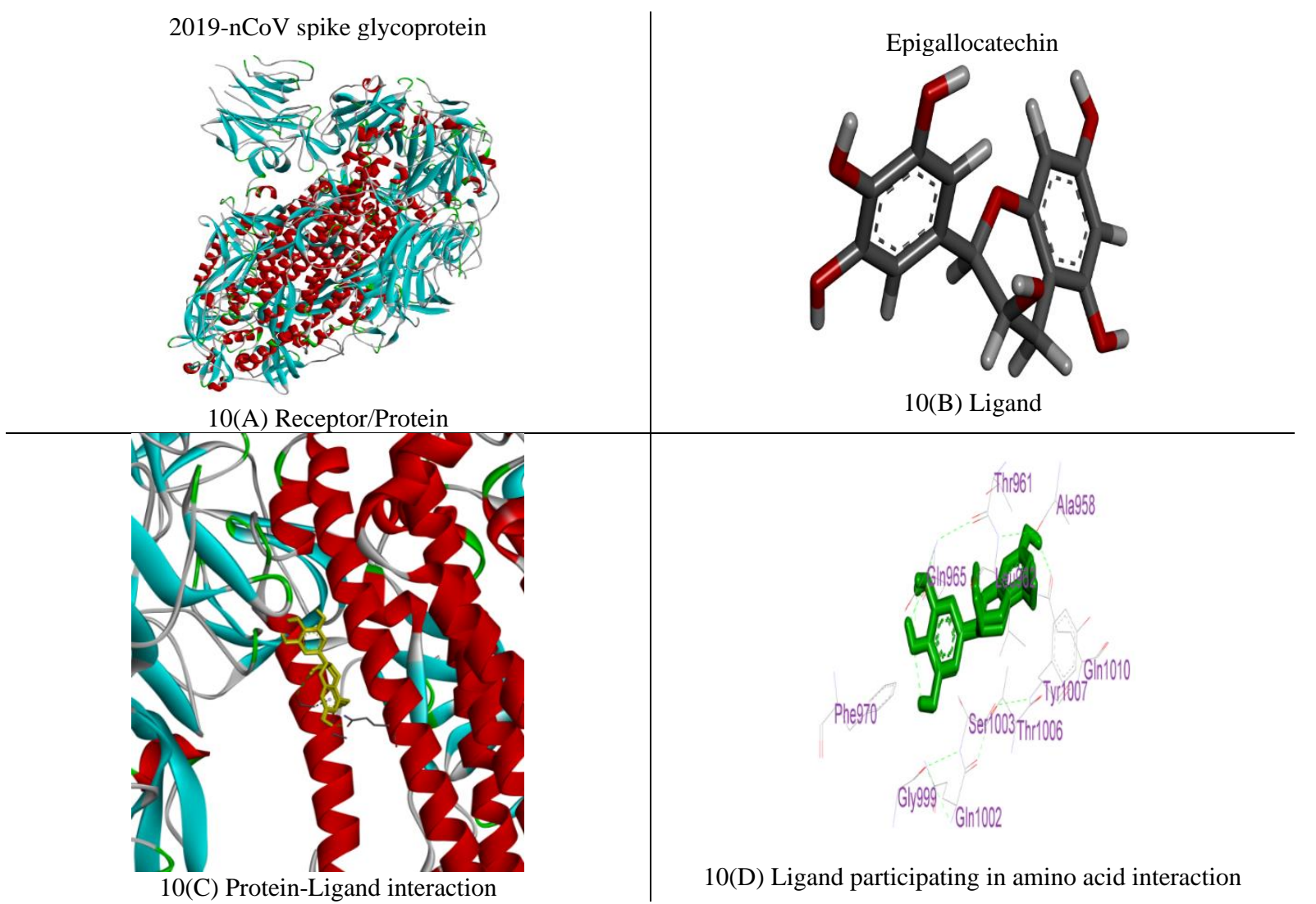

Figure 10. Molecular docking analysis between 6VSB and Epigallocatechin. (A) 3D ribbon structure of 2019nCoV spike glycoprotein (6VSB). (B) 3D ligand structure (Epigallocatechin). (C) Protein-ligand Interaction. (D) Interaction between the active site residues of ligand and protein. 


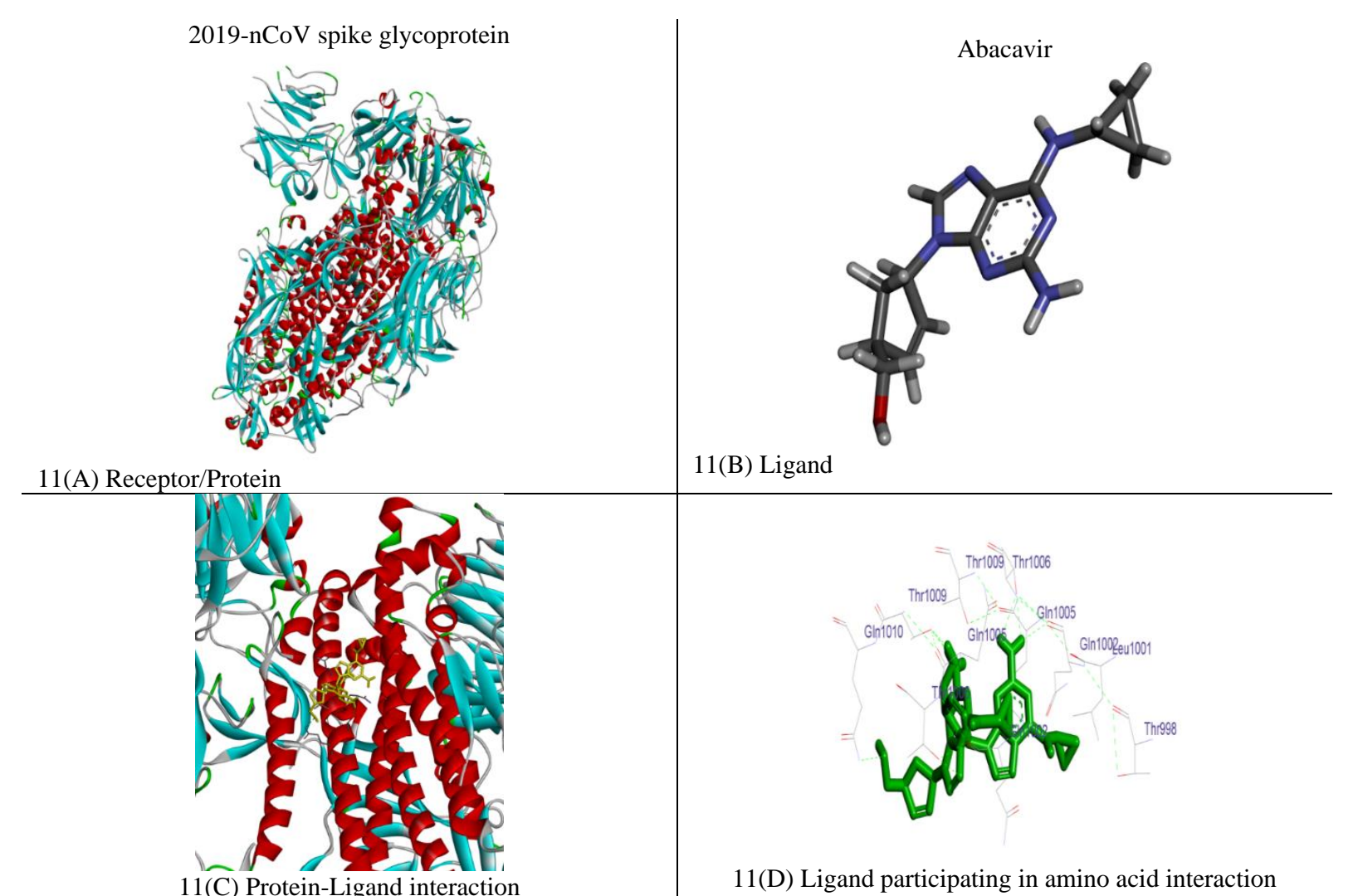

Figure 11. Molecular docking analysis between 6VSB and Abacavir. (A) 3D ribbon structure of 2019-nCoV spike glycoprotein (6VSB). (B) 3D ligand structure (Abacavir). (C) Protein-ligand Interaction. (D) Interaction between the active site residues of ligand and protein.
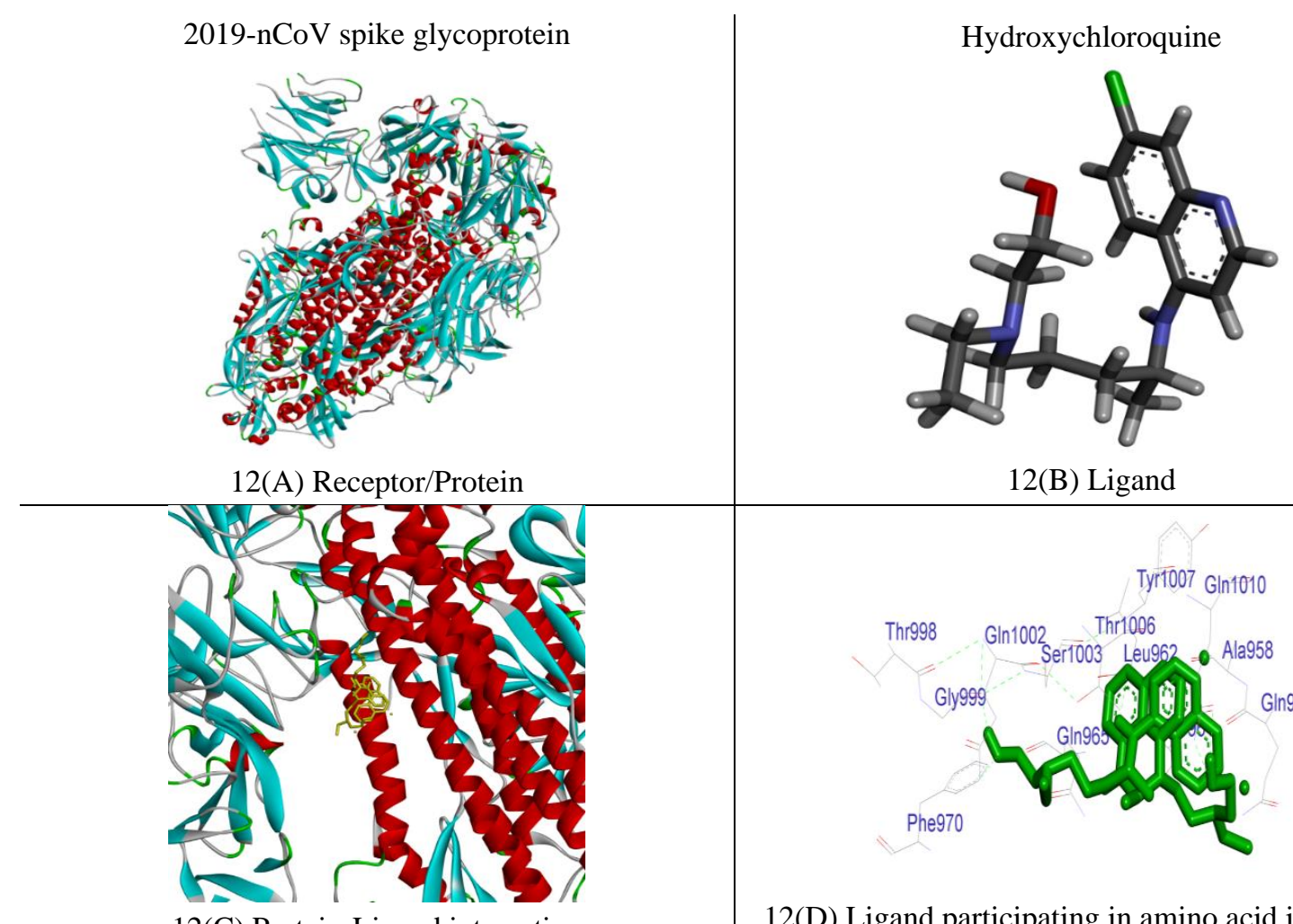

12(C) Protein-Ligand interaction

12(B) Ligand

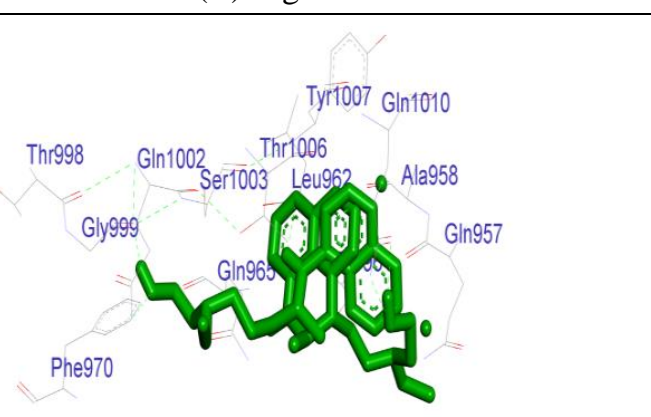

12(D) Ligand participating in amino acid interaction

Figure 12. Molecular docking analysis between 6VSB and hydroxychloroquine. (A) 3D ribbon structure of 2019-nCoV spike glycoprotein (6VSB). (B) 3D ligand structure (Hydroxychloroquine). (C) Protein ligand Interaction. (D) Interaction between the active site residues of ligand and protein. 


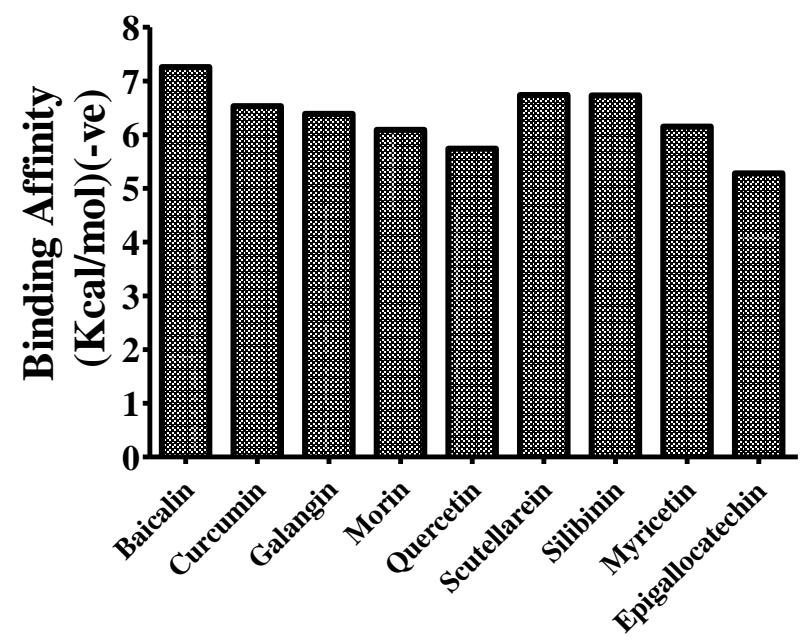

Flavonoids

Figure 13. Graphical representation of the binding affinity of all the selected 9 flavonoids with2019-nCoV spike glycoprotein.

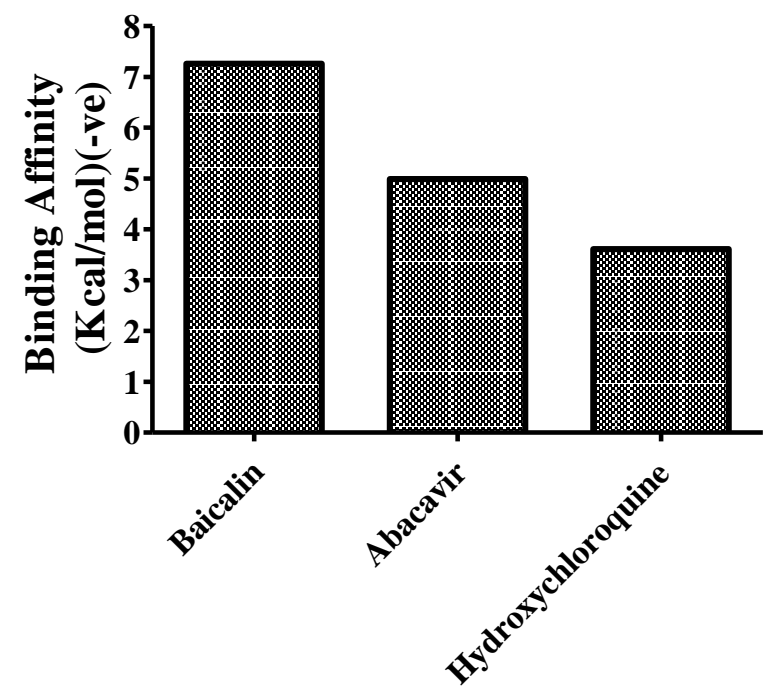

Figure 14. Comparative analysis of the best screened flavonoid with two standard drugs Abacavir and hydroxychloroquine.

\subsection{Discussion.}

Coronavirus (CoV 2019) has currently emerged as a major threat to human mankind. To date, no effective therapy or specific vaccine has been developed against this pandemic [46]. Thus these findings have motivated us to elucidate potent drug compounds against COVID-19. Computational pharmacology has gained greater attention toward improving clinical use and drug development [47]. Drug repurposing (elucidating new application of existing drugs) is one of the stimulating applications of computational pharmacology which utilizes several in silico techniques for exploring the inhibitory potential of lead (drug) compounds against several diseases [48].

In our study, we have selected Flavonoids (natural compounds) as a lead molecule for finding better therapeutics against COVID-19. Flavonoids are one of the important types of phytocompound which belong to a specific secondary metabolite of a plant (polyphenolic structure). They have exhibited significant medicinal benefits against various diseases, including Alzheimer's, cancer, atherosclerosis. Due to their anti-inflammatory, antioxidant and 
antimutagenic properties. However, some flavonoids have also shown significant antiviral potential such as HIV, Herpes, etc. [49] (Table 1). This has motivated us to select these potent flavonoids (FDA approved drugs) for the drug repurposing approach. These phytocompounds not only inhibit the virus attachment but also helps in the improvement of the immune system.

Our study was focused on the drug repurposing against the 2019-nCoV spike glycoprotein (PDB-ID: 6VSB). COVID-19 coronavirus utilizes this densely glycosylated spike (S) protein to get entry into the host cell. And because of their (S protein) indispensable role, it became a target for vaccine design and drug development. We have selected 9 potent antiviral flavonoids compounds for Molecular docking against 2019-nCoV spike glycoprotein. Molecular docking is an in silico computational approach to identify noncovalent interaction between ligand (inhibitor) and protein (target). AutoDock and PatchDock analysis clearly revealed that all the screened compounds have better inhibitory potential in comparison to the standard drug Abacavir and Hydroxychloroquine. However, baicalin has shown the best inhibitory potential against 2019-nCoV spike glycoprotein (6VSB). Therefore these experimental findings pave a strong way to further explore the potential of baicalin as a potential lead candidate for drug development against 2019-nCoV.

Table 3. Validation of docking results with the help of PatchDock (an online docking server).

\begin{tabular}{|c|c|c|c|c|c|}
\hline S. No. & Protein Name & $\begin{array}{c}\text { PubChem } \\
\text { CID }\end{array}$ & $\begin{array}{l}\text { PatchDock } \\
\text { Score }\end{array}$ & $\begin{array}{c}\text { ACE } \\
\text { Value }\end{array}$ & Complex Structure \\
\hline 1 & Baicalin & 64982 & 5686 & -316.00 & \\
\hline 2 & Curcumin & 969516 & 5630 & -189.76 & \\
\hline 3 & Galangin & 5281616 & 4344 & -209.44 & \\
\hline
\end{tabular}




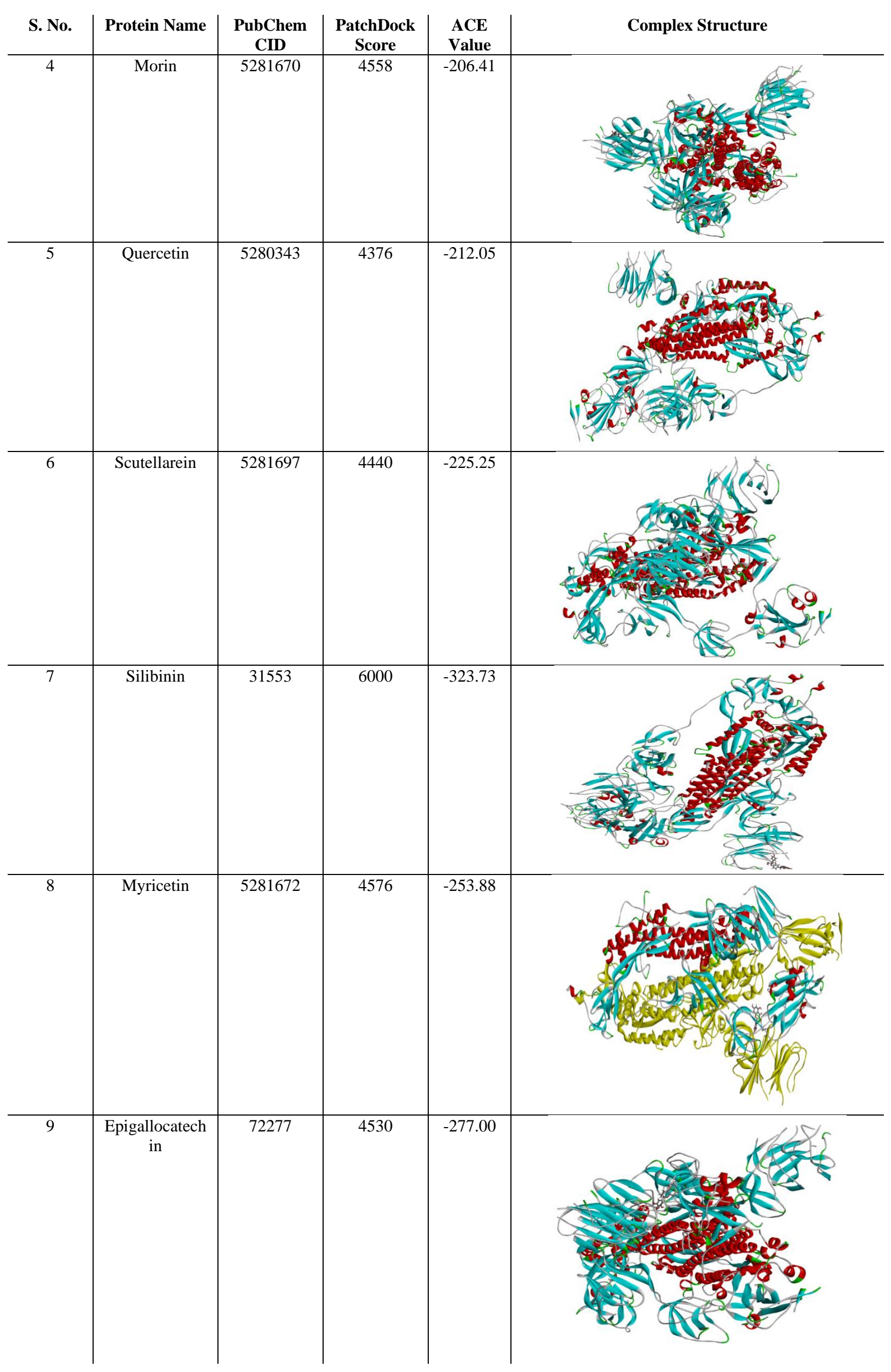




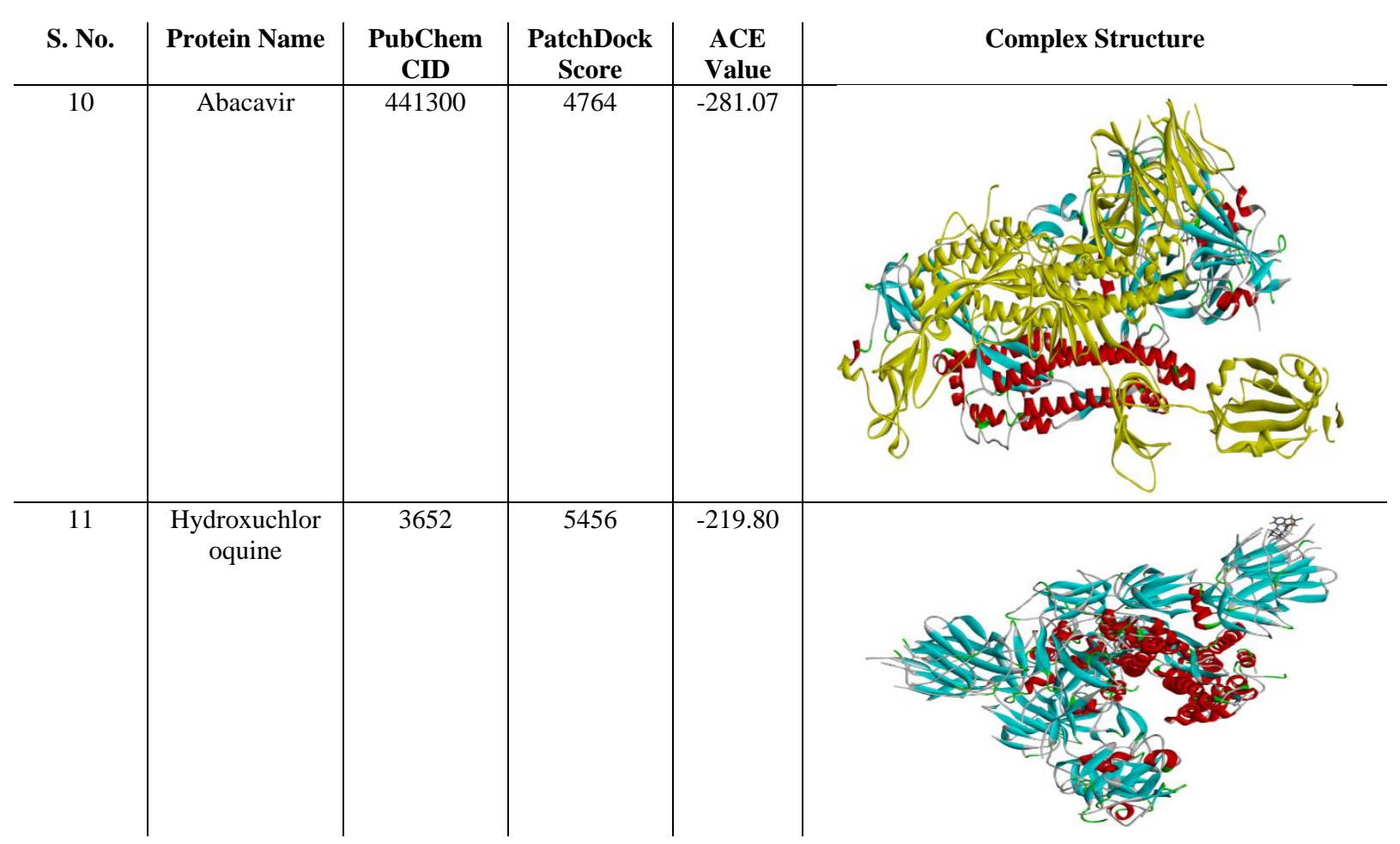

Table 4. ADME Properties of selected COVID-19 major protease inhibitors.

\begin{tabular}{|c|c|c|c|c|c|c|}
\hline \multirow[t]{2}{*}{$\begin{array}{l}\text { S. } \\
\text { No. }\end{array}$} & \multirow[t]{2}{*}{ Compound } & \multirow[t]{2}{*}{$\begin{array}{l}\text { Molecular } \\
\text { formula }\end{array}$} & \multicolumn{2}{|c|}{$\begin{array}{c}\text { ADME Properties } \\
\text { (Lipinski's Rule of Five) }\end{array}$} & \multirow[t]{2}{*}{ Structure } & \multirow[t]{2}{*}{ Drug Likeliness } \\
\hline & & & Properties & Values & & \\
\hline \multirow[t]{5}{*}{1} & \multirow[t]{5}{*}{ Baicalin } & \multirow[t]{5}{*}{$\mathrm{C} 21 \mathrm{H} 18 \mathrm{O} 11$} & $\begin{array}{c}\text { Molecular } \\
\text { Weight }(\leq 500 \\
\mathrm{Da})\end{array}$ & 446.4 & & \multirow[t]{5}{*}{ Yes } \\
\hline & & & $\operatorname{LogP}(\leq 5)$ & 1.11 & & \\
\hline & & & $\begin{array}{c}\text { H-Bond } \\
\text { Donor }(\leq 5)\end{array}$ & 6 & & \\
\hline & & & $\begin{array}{l}\text { H-Bond } \\
\text { Acceptor } \\
(\leq 10)\end{array}$ & 11 & & \\
\hline & & & Voilations & 2 & & \\
\hline \multirow[t]{5}{*}{2} & \multirow[t]{5}{*}{ Curcumin } & \multirow[t]{5}{*}{ C21H20O6 } & $\begin{array}{c}\text { Molecular } \\
\text { Weight }(\leq 500 \\
\text { Da) }\end{array}$ & 368.38 & & \multirow[t]{5}{*}{ Yes } \\
\hline & & & $\log \mathrm{P}(\leq 5)$ & 3.20 & & \\
\hline & & & $\begin{array}{c}\text { H-Bond } \\
\text { Donor }(\leq 5)\end{array}$ & 2 & & \\
\hline & & & $\begin{array}{c}\text { H-Bond } \\
\text { Acceptor } \\
(\leq 10)\end{array}$ & 6 & & \\
\hline & & & Voilations & 0 & & \\
\hline \multirow[t]{5}{*}{3} & \multirow[t]{5}{*}{ Galangin } & \multirow[t]{5}{*}{$\mathrm{C} 15 \mathrm{H} 10 \mathrm{O} 5$} & $\begin{array}{c}\text { Molecular } \\
\text { Weight }(\leq 500 \\
\mathrm{Da})\end{array}$ & 270.12 & & \multirow[t]{5}{*}{ Yes } \\
\hline & & & $\log P(\leq 5)$ & 2.25 & & \\
\hline & & & $\begin{array}{c}\text { H-Bond } \\
\text { Donor }(\leq 5)\end{array}$ & 3 & & \\
\hline & & & $\begin{array}{l}\text { H-Bond } \\
\text { Acceptor } \\
(\leq 10)\end{array}$ & 5 & & \\
\hline & & & Voilations & 0 & & \\
\hline \multirow[t]{3}{*}{4} & \multirow[t]{3}{*}{ Morin } & \multirow[t]{3}{*}{ C15H10O7 } & $\begin{array}{c}\text { Molecular } \\
\text { Weight }(\leq 500 \\
\text { Da) }\end{array}$ & 302.24 & & \multirow[t]{3}{*}{ Yes } \\
\hline & & & $\log \mathrm{P}(\leq 5)$ & 1.54 & & \\
\hline & & & $\begin{array}{c}\text { H-Bond } \\
\text { Donor }(\leq 5)\end{array}$ & 5 & & \\
\hline
\end{tabular}




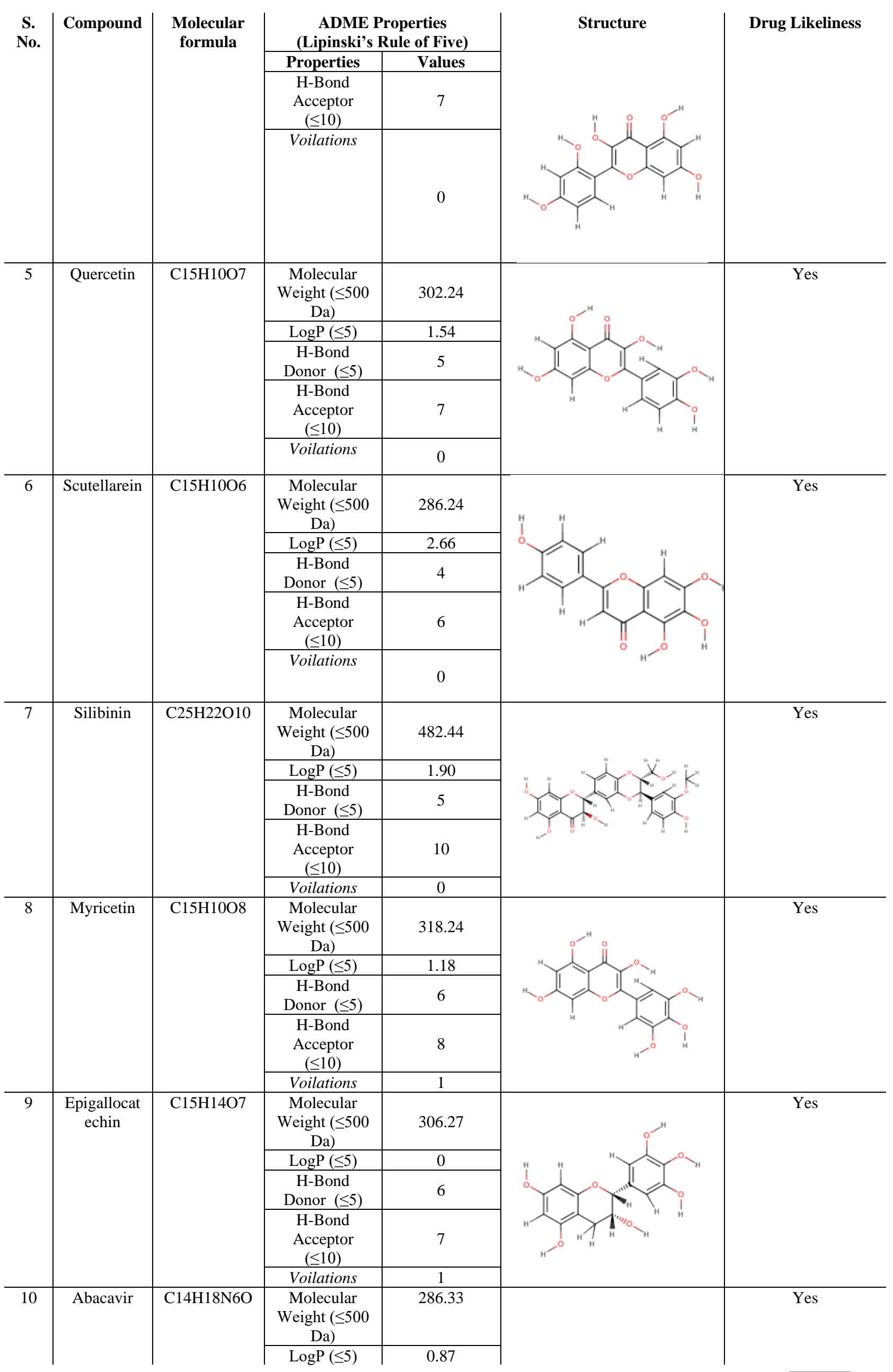

https://biointerfaceresearch.com/ 


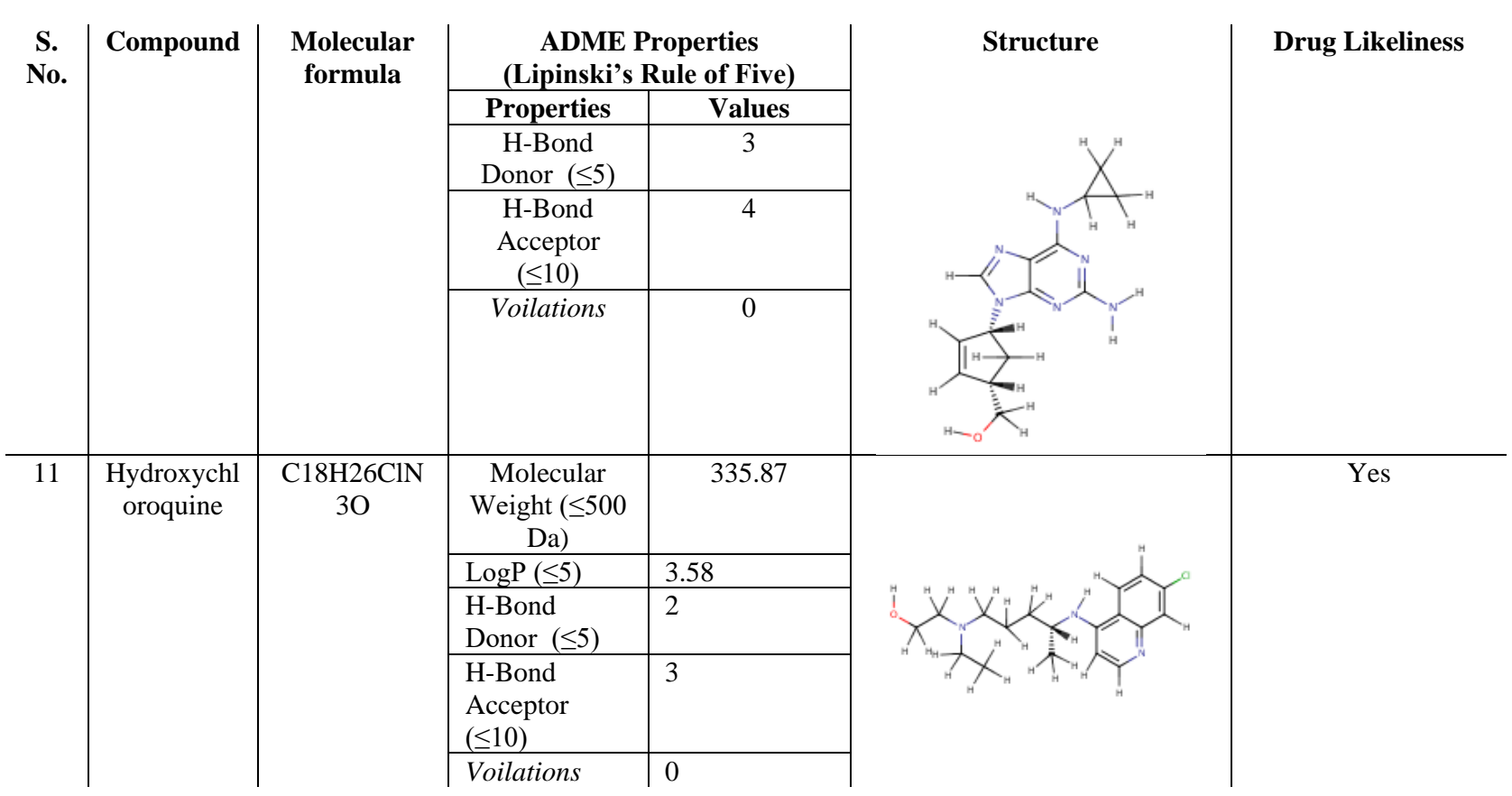

Table 5. Phytocompounds passing different Drug-Likeliness Filters.

\begin{tabular}{l|c|c|c|c|c} 
S.No. & Phyto compound & $\begin{array}{c}\text { Lipinski's rule of } \\
\text { five }\end{array}$ & Ghose filter & Veber filter & Muegge Filter \\
\hline 1. & Baicalin & $\begin{array}{c}\text { Yes (With two } \\
\text { Voilations) }\end{array}$ & Yes & No & No \\
\hline 2. & Curcumin & Yes & Yes & Yes & Yes \\
\hline 3. & Galangin & Yes & Yes & Yes & Yes \\
\hline 4. & Morin & Yes & Yes & Yes & Yes \\
\hline 5. & Quercetin & Yes & Yes & Yes & Yes \\
\hline 6. & Scutellarein & Yes & Yes & Yes & Yes \\
\hline 7. & Silibinin & Yes & Yes & Yes & Yes \\
\hline 8. & Myricetin & Yes & Yes & No & No \\
\hline 9. & Epigallocatechin & Yes & Yes & Yes & Yes
\end{tabular}

\section{Conclusions}

We have utilized the concept of a drug repurposing approach to finding a better therapeutic solution for the management of novel Coronavirus (COVID-19) disease. In silico (Bioinformatics) approach has proven to be a very useful tool to identify potent inhibitors against this disease. We have identified 9 potent inhibitors and found that baicalin can be further utilized as an appropriate inhibitor against COVID-19, which could be further explored to develop a potent drug molecule against Corona disease (COVID-19) with minimal side effects and numerous health benefits.

\section{Funding}

This research received no external funding.

\section{Acknowledgments}

The authors thank the management of Noida Institute of Engineering \& Technology and Lucknow University for providing the facilities to carry out this study. 


\section{Conflicts of Interest}

\section{The authors declare no conflict of interest.}

\section{References}

1. Drosten, C.; Preiser, W.; Günther, S.; Schmitz, H.; Doerr, H.W. Severe acute respiratory syndrome: identification of the etiological agent. Trends in Molecular Medicine 2003, 9, 325-327, https://doi.org/10.1016/S1471-4914(03)00133-3.

2. Alsahafi, A.J.; Cheng, A.C. The epidemiology of Middle East respiratory syndrome coronavirus in the Kingdom of Saudi Arabia, 2012\&\#x2013;2015. International Journal of Infectious Diseases 2016, 45, 1-4, https://doi.org/10.1016/j.ijid.2016.02.004.

3. Lan, J.; Ge, J.; Yu, J.; Shan, S.; Zhou, H.; Fan, S.; Zhang, Q.; Shi, X.; Wang, Q.; Zhang, L.; Wang, X. Structure of the SARS-CoV-2 spike receptor-binding domain bound to the ACE2 receptor. Nature 2020, 581, 215-220, https://doi.org/10.1038/s41586-020-2180-5.

4. Denison, M.R.; Graham, R.L.; Donaldson, E.F.; Eckerle, L.D.; Baric, R.S. Coronaviruses. RNA Biology 2011, 8, 270-279, https://doi.org/10.4161/rna.8.2.15013.

5. World Health Organization. Clinical care for severe acute respiratory infection: toolkit: COVID-19 adaptation. No. WHO/2019-nCoV/SARI_toolkit/2020.1. World Health Organization, 2020.

6. Corsello, S.M.; Bittker, J.A.; Liu, Z.; Gould, J.; McCarren, P.; Hirschman, J.E.; Johnston, S.E.; Vrcic, A.; Wong, B.; Khan, M.; Asiedu, J.; Narayan, R.; Mader, C.C.; Subramanian, A.; Golub, T.R. The Drug Repurposing Hub: a next-generation drug library and information resource. Nature Medicine 2017, 23, 405408, https://doi.org/10.1038/nm.4306.

7. Wrapp, D.; Wang, N.; Corbett, K.S.; Goldsmith, J.A.; Hsieh, C.-L.; Abiona, O.; Graham, B.S.; McLellan, J.S. Cryo-EM structure of the 2019-nCoV spike in the prefusion conformation. Science 2020, 367, 12601263, https://doi.org/10.1126/science.abb2507.

8. Walls, A.C.; Park, Y.J.; Tortorici, M.A.; Wall, A.; McGuire, A.T.; Veesler, D. Structure, function, and antigenicity of the SARS-CoV-2 spike glycoprotein. Cell 2020, https://doi.org/10.1016/j.cell.2020.02.058.

9. Rizvi, S.M.; Shakil, S.; Haneef, M. A simple click by click protocol to perform docking: AutoDock 4.2 made easy for non-bioinformaticians. EXCLI journal 2013, 12, 831-857.

10. Schneidman-Duhovny, D.; Inbar, Y.; Nussinov, R.; Wolfson, H.J. PatchDock and SymmDock: servers for rigid and symmetric docking. Nucleic Acids Res 2005, 33, W363-W367, https://doi.org/10.1093/nar/gki481.

11. Blanco, J.L.; Ambrosioni, J.; Garcia, F.; Martínez, E.; Soriano, A.; Mallolas, J.; Miro, J.M.; Investigators, C.I.H. COVID-19 in patients with HIV: clinical case series. Lancet HIV 2020, 7, e314-e316, https://doi.org/10.1016/S2352-3018(20)30111-9.

12. Kitamura, K.; Honda, M.; Yoshizaki, H.; Yamamoto, S.; Nakane, H.; Fukushima, M.; Ono, K.; Tokunaga, T. Baicalin, an inhibitor of HIV-1 production in vitro. Antiviral Research 1998, 37, 131-140, https://doi.org/10.1016/S0166-3542(97)00069-7.

13. Oo, A.; Teoh, B.T.; Sam, S.S.; Bakar, S.A.; Zandi, K. Baicalein and baicalin as Zika virus inhibitors. Archives of Virology 2019, 164, 585-593 https://doi.org/10.1007/s00705-018-4083-4.

14. Tamayose, C.I.; Torres, P.B.; Roque, N.; Ferreira, M.J.P. HIV-1 reverse transcriptase inhibitory activity of flavones and chlorogenic acid derivatives from Moquiniastrum floribundum (Asteraceae). South African Journal of Botany 2019, 123, 142-146, https://doi.org/10.1016/j.sajb.2019.02.005.

15. Ahmed, M.B.; Hanan, E.; Osama, O.; Kholmirzo, T.K.; Tarek, H.; Medhat, A.I. Effect of nano metal oxides on heme molecule: molecular and biomolecular approaches. Biointerface Res. Appl. Chem. 2020, 10, https://doi.org/10.33263/BRIAC101.837845.

16. da Silva, T.A.L.; Medeiros, R.M.V.; de Medeiros, D.C.; Medeiros, R.C.S.C.; de Medeiros, J.A.; de Medeiros, G.C.B.S.; de Andrade, R.D.; Lais, L.L.; Silva Dantas, P.M. Impact of curcumin on energy metabolism in HIV infection: A case study. Phytotherapy Research 2019, 33, 856-858, https://doi.org/10.1002/ptr.6258.

17. Dorothy D.; Mridusmita K.; Aroon G.; Airy S.; Swarna M. P.; Venkata S. K. M. Screening of druggable conformers of $\alpha$-synuclein using molecular dynamics simulation. Biointerface Res. Appl. Chem. 2020, 10, 1-10, https://doi.org/10.33263/BRIAC103.338347.

18. Sharma, A.; Yadav, A.; Gupta, N.; Sharma, S.; Kakkar, R.; Cwiklinski, K.; Quaye, E.; Mahajan, S.D.; Schwartz, S.A.; Kumar Sharma, R. Multifunctional mesoporous curcumin encapsulated iron-phenanthroline nanocluster: A new Anti-HIV agent. Colloids and Surfaces B: Biointerfaces 2019, 180, 289-297, https://doi.org/10.1016/j.colsurfb.2019.04.057.

19. Majid, M.; Sara, S.; Fatemeh, M. Evaluation of Coronavirus Families \& Covid-19 Proteins: Molecular Modeling Study. Biointerface Res. Appl. Chem. 2020, 10, https://doi.org/10.33263/BRIAC105.60396057.

20. Prinsloo, G.; Marokane, C.K.; Street, R.A. Anti-HIV activity of southern African plants: Current developments, phytochemistry and future research. Journal of Ethnopharmacology 2018, 210, 133-155, https://doi.org/10.1016/j.jep.2017.08.005. 
21. Brinkworth, R.I.; Stoermer, M.J.; Fairlie, D.P. Flavones are inhibitors of HIV-1 proteinase. Biochemical and Biophysical Research Communications 1992, 188, 631-637, https://doi.org/10.1016/0006-291X(92)91103W.

22. Prinsloo, G.; Marokane, C.K.; Street, R.A. Anti-HIV activity of southern African plants: Current developments, phytochemistry and future research. Journal of Ethnopharmacology 2018, 210, 133-155, https://doi.org/10.1016/j.jep.2017.08.005.

23. Anna, C.; Paolo, C.; Alice, S.; Paolo, P. Morin: A Promising Natural Drug. Current Medicinal Chemistry 2016, 23, 774-791, https://doi.org/10.2174/0929867323666160106150821.

24. Kataria, R.; Khatkar, A. Molecular docking, synthesis, kinetics study, structure-activity relationship and ADMET analysis of morin analogous as Helicobacter pylori urease inhibitors. BMC Chemistry 2019, 13, https://doi.org/10.1186/s13065-019-0562-2.

25. Wu, W.; Li, R.; Li, X.; He, J.; Jiang, S.; Liu, S.; Yang, J. Quercetin as an Antiviral Agent Inhibits Influenza A Virus (IAV) Entry. Viruses 2016, 8, https://doi.org/10.3390/v8010006.

26. Wong, G.; He, S.; Siragam, V.; Bi, Y.; Mbikay, M.; Chretien, M.; Qiu, X. Antiviral activity of quercetin-3$\beta$-O-D-glucoside against Zika virus infection. Virologica Sinica 2017, 32, 545-547, https://doi.org/10.1007/s12250-017-4057-9.

27. Rojas, Á.; Del Campo, J.A.; Clement, S.; Lemasson, M.; García-Valdecasas, M.; Gil-Gómez, A.; Ranchal, I.; Bartosch, B.; Bautista, J.D.; Rosenberg, A.R.; Negro, F.; Romero-Gómez, M. Effect of Quercetin on Hepatitis C Virus Life Cycle: From Viral to Host Targets. Scientific Reports 2016, 6, 1-9, https://doi.org/10.1038/srep31777.

28. Iloghalu, U.; Bryce H.; Janak K.; Leonard L. W. Selected Plant Extracts Show Antiviral Effects against Murine Norovirus Surrogate. Adv Microbiol. 2019, 9, https://doi.org/10.4236/aim.2019.94022.

29. Chandel, V.; Raj, S.; Rathi, B.; Kumar, D. In Silico Identification of Potent COVID-19 Main Protease Inhibitors from FDA Approved Antiviral Compounds and Active Phytochemicals through Molecular Docking: A Drug Repurposing Approach. https://doi.org/10.20944/preprints202003.0349.v1.

30. Li, W.; Xu, C.; Hao, C.; Zhang, Y.; Wang, Z.; Wang, S.; Wang, W. Inhibition of herpes simplex virus by myricetin through targeting viral gD protein and cellular EGFR/PI3K/Akt pathway. Antiviral Research 2020, 177, https://doi.org/10.1016/j.antiviral.2020.104714.

31. Islam, M.T.; Sarkar, C.; El-Kersh, D.M.; Jamaddar, S.; Uddin, S.J.; Shilpi, J.A.; Mubarak, M.S. Natural products and their derivatives against coronavirus: A review of the non-clinical and pre-clinical data. Phytotherapy Research 2020, https://doi.org/10.1002/ptr.6700.

32. Elmezayen, A.D.; Al-Obaidi, A.; Şahin, A.T.; Yelekçi, K. Drug repurposing for coronavirus (COVID-19): in silico screening of known drugs against coronavirus 3CL hydrolase and protease enzymes. Journal of Biomolecular Structure and Dynamics 2020, 1-13, https://doi.org/10.1080/07391102.2020.1758791.

33. Liu, C.H.; Jassey, A.; Hsu, H.Y.; Lin, L.T. Antiviral Activities of Silymarin and Derivatives. Molecules 2019, 24, https://doi.org/10.3390/molecules24081552.

34. Lalani, S.; Poh, C.L. Flavonoids as Antiviral Agents for Enterovirus A71 (EV-A71). Viruses 2020, 12, https://doi.org/10.3390/v12020184.

35. Tang, X.; Zhang, C.; Chen, M.; Xue, Y.; Liu, T.; Xue, W. Synthesis and antiviral activity of novel myricetin derivatives containing ferulic acid amide scaffolds. New Journal of Chemistry 2020, 44, 2374-2379, https://doi.org/10.1039/C9NJ05867B.

36. Joshi, R.S.; Jagdale, S.S.; Bansode, S.B.; Shankar, S.S.; Tellis, M.B.; Pandya, V.K.; Chugh, A.; Giri, A.P.; Kulkarni, M.J. Discovery of potential multi-target-directed ligands by targeting host-specific SARS-CoV-2 structurally conserved main protease. Journal of Biomolecular Structure and Dynamics 2020, https://doi.org/10.1080/07391102.2020.1760137.

37. Ortega, J.T.; Suárez, A.I.; Serrano, M.L.; Baptista, J.; Pujol, F.H.; Rangel, H.R. The role of the glycosyl moiety of myricetin derivatives in anti-HIV-1 activity in vitro. AIDS Research and Therapy 2017, 14, https://doi.org/10.1186/s12981-017-0183-6.

38. Vázquez-Calvo, Á.; Jiménez de Oya, N.; Martín-Acebes, M.A.; Garcia-Moruno, E.; Saiz, J.-C. Antiviral Properties of the Natural Polyphenols Delphinidin and Epigallocatechin Gallate against the Flaviviruses West Nile Virus, Zika Virus, and Dengue Virus. Frontiers in microbiology 2017, 8, 1314-1314, https://doi.org/10.3389/fmicb.2017.01314

39. Zhang, Y.; Wang, H.; Su, M.; Lu, L. (-)-Epicatechin gallate, a metabolite of (-)-epigallocatechin gallate in grass carp, exhibits antiviral activity in vitro against grass carp reovirus. Aquaculture Research 2020, 51, 1673-1680, https://doi.org/10.1111/are.14513.

40. Dong, L.; Hu, S.; Gao, J. Discovering drugs to treat coronavirus disease 2019 (COVID-19). Drug Discoveries \& Therapeutics 2020, 14, 58-60, https://doi.org/10.5582/ddt.2020.01012.

41. Mungroo, M.R.; Khan, N.A.; Siddiqui, R. Novel Coronavirus: Current Understanding of Clinical Features, Diagnosis, Pathogenesis, and Treatment Options. Pathogens 2020, 9, https://doi.org/10.3390/pathogens9040297. 
42. Beck, B.R.; Shin, B.; Choi, Y.; Park, S.; Kang, K. Predicting commercially available antiviral drugs that may act on the novel coronavirus (2019-nCoV), Wuhan, China through a drug-target interaction deep learning model. bioRxiv 2020, https://doi.org/10.1101/2020.01.31.929547.

43. Gautret, P.; Lagier, J.C.; Parola, P.; Hoang, V.T.; Meddeb, L.; Mailhe, M.; Doudier, B.; Courjon, J.; Giordanengo, V.; Vieira, V.E.; Tissot Dupont, H.; Honoré, S.; Colson, P.; Chabrière, E.; La Scola, B.; Rolain, J.-M.; Brouqui, P.; Raoult, D. Hydroxychloroquine and azithromycin as a treatment of COVID-19: results of an open-label non-randomized clinical trial. International Journal of Antimicrobial Agents 2020, https://doi.org/10.1016/j.ijantimicag.2020.105949.

44. Singh, B.; Hannah R.; Tamara K.; Marty C.; Tom F. Chloroquine or hydroxychloroquine for prevention and treatment of COVID-19. Cochrane Database Syst Rev. 2020, 4, https://doi.org/10.1002/14651858.CD013587.

45. Duhovny, D.; Ruth, N.; Haim, J. W. Efficient unbound docking of rigid molecules. In: International workshop on algorithms in bioinformatics. 2002; pp. 185-200, https://doi.org/10.1007/3-540-45784-4_14.

46. Dawood, A.A. Mutated COVID-19 may foretell a great risk for mankind in the future. New Microbes and New Infections 2020, 35, https://doi.org/10.1016/j.nmni.2020.100673.

47. Hodos, R.A.; Kidd, B.A.; Shameer, K.; Readhead, B.P.; Dudley, J.T. In silico methods for drug repurposing and pharmacology. Wiley interdisciplinary reviews. Systems biology and medicine 2016, 8, 186-210, https://doi.org/1186-210. 10.1002/wsbm.1337.

48. Corsello, S.M.; Bittker, J.A.; Liu, Z.; Gould, J.; McCarren, P.; Hirschman, J.E.; Johnston, S.E.; Vrcic, A.; Wong, B.; Khan, M.; Asiedu, J.; Narayan, R.; Mader, C.C.; Subramanian, A.; Golub, T.R. The Drug Repurposing Hub: a next-generation drug library and information resource. Nature Medicine 2017, 23, 405408, https://doi.org/10.1038/nm.4306.

49. Zakaryan, H.; Arabyan, E.; Oo, A.; Zandi, K. Flavonoids: promising natural compounds against viral infections. Archives of Virology 2017, 162, 2539-2551, https://doi.org/10.1007/s00705-017-3417-y.

50. Alsayed, R.; Kadhom, M.;Yousif, E.;Sabir, DK. An Epidemiological Characteristic of the COVID-19 Among Children. Letters in Applied Nano BioScience 2020, 9, 1156-1164, https://doi.org/10.33263/LIANBS93.11561164 